\title{
Characterisation and development of Early Cretaceous shelf platform deposition and faulting in the Hoop area, southwestern Barents Sea-constrained by high-resolution seismic data
}

\author{
Thea Sveva Faleide', Ivar Midtkandal', Sverre Planke',3, Romain Corseri², \\ Jan Inge Faleide', 3 , Christopher Sæbø Serck' \& Johan Petter Nystuen' \\ ${ }^{1}$ Department of Geosciences, University of Oslo, Box 1047 Blindern, N-0316 Oslo, Norway. \\ ${ }^{2}$ Volcanic Basin Petroleum Research AS, Oslo Research Park, Gaustadalléen 21, N-0349 Oslo, Norway. \\ ${ }^{3}$ The Centre for Earth Evolution and Dynamics, University of Oslo, Box 1028 Blindern, N-0315 Oslo, Norway.
}

E-mail corresponding author (Thea Sveva Faleide): t.s.faleide@geo.uio.no.

Regional Early Cretaceous uplift of the northern Barents Sea associated with the High Arctic Large Igneous Province (HALIP) caused the development of the fluvial to open-marine depositional system, terminating in the southwestern Barents Sea. This study has established a new temporal and spatial evolution of the Lower Cretaceous deposits in the Hoop area, in particular the location and age of the intrashelf platform lobe front and subsequent block-faulting. A composite high-resolution 3D and 2.5D P-Cable and conventional 3D seismic dataset image the strata and cross-cutting faults in the Hoop area. The P-Cable data typically have a resolution of 3-7 $\mathrm{m}$ in the shallow subsurface, up to four times better than the conventional seismic data, contributing to a new and better mapping hence understanding of the Lower Cretaceous strata and faults. Seismic horizon and facies mapping reveal large-scale clinoforms, with present-day heights of $150-200 \mathrm{~m}$ and dips of $0.65-1.13^{\circ}$. The highresolution data furthermore display complex stratigraphic and structural features, such as small-scale clinoforms and numerous faults. The shelf platform succession is block-faulted, and the main Early Cretaceous fault activity thus postdates the arrival of the delta and platform sediments from the northwest. Detailed seismo-stratigraphic ties to the 7324/2-1 (Apollo) and 7325/1-1 (Atlantis) wells, and ties to the adjacent Fingerdjupet Subbasin, document a Barremian age for the shelf platform deposits and an Aptian?-early Albian age for the main faulting event. The faulting was likely initiated in the Aptian, but a hiatus or condensed section above the Barremian strata makes it difficult to constrain the onset of deformation in the Hoop area.

Keyword: Barremian, intrashelf platform lobe, clinoforms, high-resolution seismic, Early Cretaceous faulting, Barents Sea.

Electronic Supplement 1: Power spectrum

Electronic Supplement 2: Well-log data

Electronic Supplement 3: High-resolution seismic data

Electronic Supplement 4: Seismic lines

Received 29. January 2019 / Accepted 10. July 2019 / Published online X

Faleide, T.S., Midtkandal, I., Planke, S., Corseri, R., Faleide, J.I., Serck, C.S. \& Nystuen, J.P. 2019: Characterisation and development of Early Cretaceous shelf platform deposition and faulting in the Hoop area, southwestern Barents Sea-constrained by high-resolution seismic data. Norwegian Journal of Geology 99, 1-20. https://dx.doi.org/10.17850/njg99-3-7. 


\section{Introduction}

Controlling factors of clastic infill of epicontinental basins and shelves are diverse and complex. They include pre- and syn-depositional tectonics, climate and sealevel variation as factors in control of basin geometry, provenance areas and sediment routing, accommodation, water depth and seafloor topography, as well as sediment influx, grain size and energy systems in time and space (rivers, waves, tides and gravity) (Johnson \& Baldwin, 1996). Large river and deltaic systems are first-order sensitive recorders of these factors, as reflected in high-resolution seismic data, in particular clinoform geometries of intrashelf platform lobes (Cattaneo et al., 2003; Liu et al., 2004; Yang \& Liu, 2007; Mountain \& Proust, 2010; Li et al., 2014; Maselli et al., 2014; Pellegrini et al., 2015; Patruno \& Helland-Hansen, 2018).

A regional understanding of the Early Cretaceous Barents Sea geological history and resultant stratigraphy is crucial in order to explain the deposition and timing of the Lower Cretaceous succession both on Svalbard (proximal) and in the southwestern Barents Sea (distal). The Barents Sea has a long history as one of world's largest epicontinental seas (Worsley, 2008; Smelror et al., 2009). Since Mesozoic times, the Barents Sea, being a part of the polar basin, has been dominated by siliciclastic sedimentation with sediment influx from the south, southeast, east and northwest, commonly as large fluvial to deltaic systems and their distal-marine contemporaneous environments (e.g., Worsley, 2008; Glørstad-Clark et al., 2010; Grundvåg et al., 2017; Klausen et al., 2014, 2019; Midtkandal et al., 2019a).

One of the largest depositional systems was established during the Early Cretaceous by a fluvial to open-marine system that prograded southeastwards from a source area northwest of Svalbard into the epicontinental sea located in the present-day southwestern Barents Sea (Midtkandal \& Nystuen, 2009; Grundvåg et al., 2017; Midtkandal et al., 2019a). The northern source area was uplifted in association with the early development and doming of the High Arctic Large Igneous Province (HALIP; Maher, 2001; Senger et al., 2014; Polteau et al., 2016; Midtkandal et al., 2019a) causing a large-scale N-S tilt and basin deepening towards the southeast, and the Barremian fluvial to marine sedimentation (Fig. 1).

The study area, informally termed "the Hoop area", is centred around the Hoop Fault Complex (Gabrielsen et al., 1990), which places it within the Bjarmeland Platform east of the neighbouring Fingerdjupet Subbasin and northeast of the Loppa High and Maud Basin (Fig.

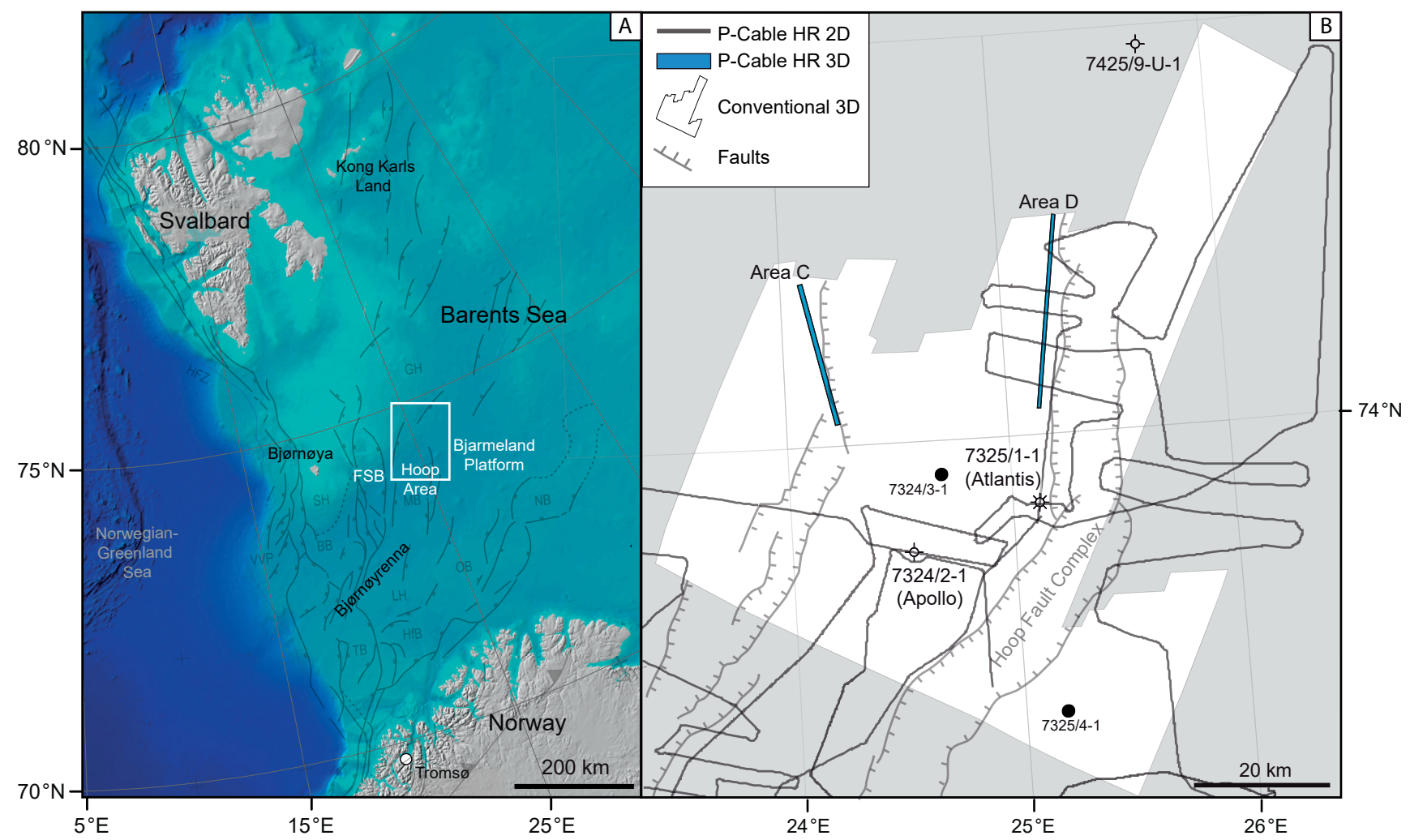

Figure 1. (A) Location of the study area (white box) in the Hoop area with reference to Svalbard and the Norwegian mainland on a bathymetry map based on Jakobsson et al. (2012). Structural elements are modified from Faleide et al. (2015). (B) Seismic data coverage and wells within the study area with the main faults marked. Abbreviations: BB - Bjørnøya Basin, FSB - Fingerdjupet Subbasin, GH - Gardarbanken High, HfB - Hammerfest Basin, LH - Loppa High, MB - Maud Basin, NB - Nordkapp Basin, OB - Ottar Basin, SH - Stappen High, TB - Tromsø Basin, VVP - Vestbakken Volcanic Province. 
1A). The area is defined by its oppositely verging $\mathrm{N}-\mathrm{S}$ trending faults.

In the Hoop area, the Barremian sedimentary succession is imaged as a $\sim 200 \mathrm{~ms}$ package composed of SE-prograding clinothems in seismic profiles, and is considered to represent an intrashelf siliciclastic platform that developed as the most distal component of the aforementioned sedimentary transport system. This sediment wedge, termed depositional lobe NW2, in accordance with Midtkandal et al. (2019a, b), is the main study object. The stratigraphy below and above this unit is included to provide a regional context for the basin succession and basin development.

This study complements the work presented in Midtkandal et al. (2019a, b), with emphasis on detailed observations made possible by the high-resolution P-Cable and conventional 3D seismic data. It addresses the main characteristics of the depositional platform lobe system such as clinoform geometries, terminations, progradation direction and timing, based on integrated analysis of seismic and well data. With the highresolution data, otherwise unresolved stratigraphic and structural architectures are imaged and add details to the geological development. The results are correlated to the Lower Cretaceous sedimentary succession on Svalbard, which was part of the same regional depositional system (Fig. 2A), but separated by a $\sim 300 \mathrm{~km}$-broad erosional gap due to Cenozoic uplift and erosion (Midtkandal et al., 2007, 2014, 2019a; Midtkandal \& Nystuen, 2009; Grundvåg et al., 2017). Another key objective relates to the timing and regional implications of Early Cretaceous faulting within the Hoop area compared to the adjacent Fingerdjupet Subbasin (Serck et al., 2017). Utilising the high-resolution seismic data we also address the nature of the lowermost Cretaceous downlap surface of the intrashelf platform lobe (LCU; Midtkandal et al., 2019a, b) and its relationship to the underlying so-called Base Cretaceous Unconformity (BCU). Finally, the results are considered in the light of recent works (e.g., Grundvåg et al., 2017; Marín et al., 2017; Serck et al., 2017; Midtkandal et al., 2019a, b) focusing on similarities and differences in their views on the temporal and spatial evolution of the NW-sourced intrashelf platform lobe system.

\section{Geological framework}

The Lower Cretaceous succession in the Barents Sea belongs to the Adventdalen Group (Parker, 1967; Mørk et al., 1999, references therein), and is subdivided into the Knurr, Klippfisk, Kolje and Kolmule formations (Fig. 2B). The Knurr and Klippfisk formations developed concurrently during the Berriasian to early Barremian (Worsley et al., 1988). The Knurr Formation represents basinal development, while the Klippfisk Formation was deposited in platform areas and at local structural highs (Smelror et al., 1998; Mørk et al., 1999; Bugge et al., 2002), or in distal shelf areas devoid of siliciclastic input (Midtkandal et al., 2019a). The Knurr Formation consists of claystone and thin limestone/dolomite interbeds in addition to a thin sandstone in the lower part (Smelror et al., 1998; NPD, 2017). The Klippfisk Formation represents a condensed interval dominated by limestones which grade into marls and calcareous claystones laterally towards deeper parts of the shelf (Smelror et al., 1998). The Barremian-Aptian Kolje Formation is dominated by mudstones, with minor limestone and dolomite beds, along with thin interbeds of siltstone and sandstone in the upper part (Worsley et al., 1988). It was deposited in a distal open-marine environment. The base of Kolje Formation is described as a regional unconformity of Barremian age, termed the Lower Cretaceous Unconformity (LCU) in Midtkandal et al. (2019a). The Kolmule Formation, of AlbianCenomanian age, consists mainly of claystone and shale deposited in a shallow-marine environment, influenced by changes in sea level and sediment supply (Smelror et al., 2009). In the Hoop area, the Kolmule Formation is bounded at the top by a regional unconformity (Fig. 2B) associated with Cenozoic uplift and erosion causing removal of 2200-2400 m of Cretaceous-Paleogene strata (Henriksen et al., 2011; Baig et al., 2016).

On Svalbard, the Cretaceous part of the Adventdalen Group contains, from oldest to youngest, the Rurikfjellet, Helvetiafjellet and Carolinefjellet formations (Fig. 2B; Dallmann, 1999, 2015; Grundvåg et al., 2019). The Rurikfjellet Formation is laterally equivalent to the Knurr and Klippfisk formations in the Barents Sea (Fig. 2B), deposited in Valanginian to Hauterivian time (Dypvik et al., 2002; Jelby et al., 2018). The Helvetiafjellet Formation rests unconformably on the Rurikfjellet Formation, and consists of a lower sandstone- and conglomeratedominated fluvial unit, followed by an upper heterolithic unit of alternating sandstone, carbonaceous shale and thin coal, deposited in a marginal marine environment in early Barremian-early Aptian time (Parker, 1967; Nemec, 1992; Gjelberg \& Steel, 1995; Midtkandal et al., 2007; Midtkandal \& Nystuen, 2009). During the AptianAlbian, the Carolinefjellet Formation was deposited on a distally deepening, open-marine, storm-dominated shelf and consists of alternating sandstone and shale (Dallmann, 2015; Hurum et al., 2016; Grundvåg \& Olaussen, 2017). The lower part, together with the Helvetiafjellet Formation, is laterally equivalent to the Kolje Formation in the Barents Sea, while the rest of the Carolinefjellet Formation correlates with the Kolmule Formation (Fig. 2B; Antonsen et al., 1991; Grundvåg et al., 2017; Midtkandal et al., 2019a).

There are two main Lower Cretaceous depositional lobe systems in the Barents Sea with different source areas; one from the northwest (focus for this study) and one 

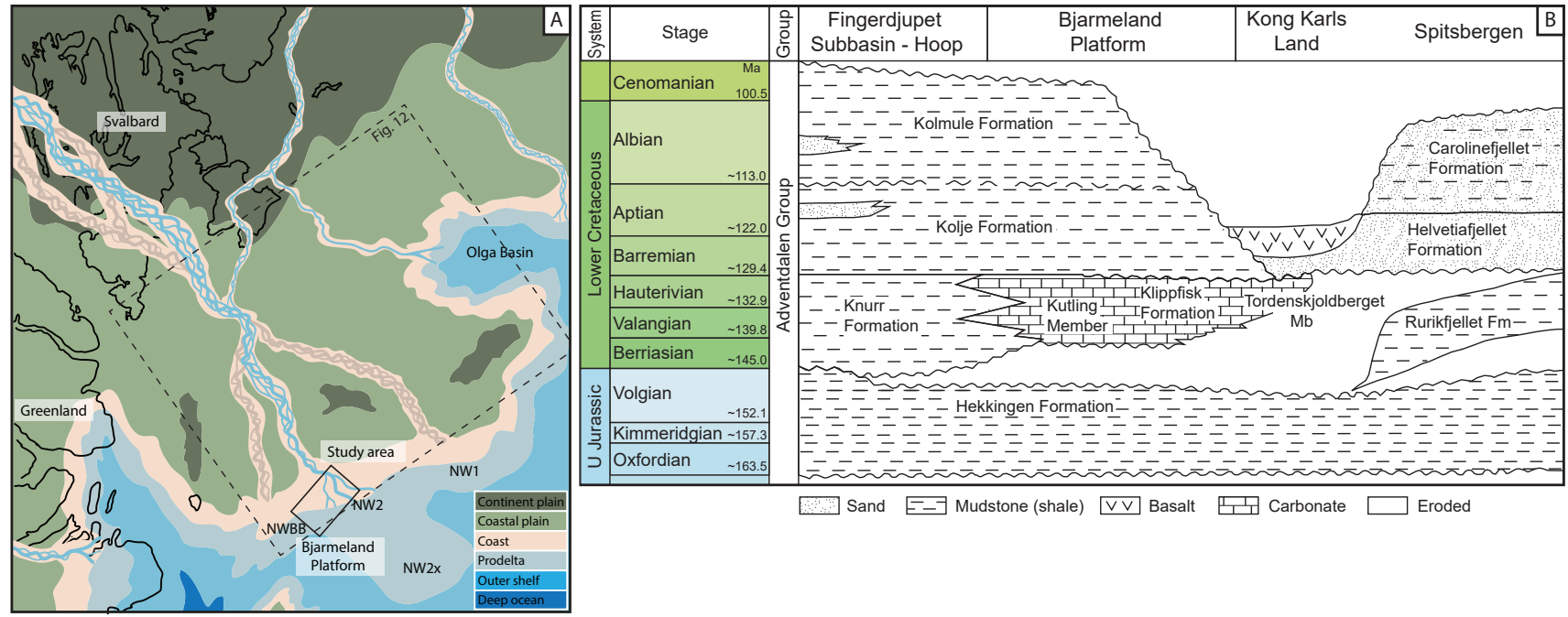

Figure 2. Regional setting for the NW-SE, Early Cretaceous, fluvial to open-marine system and correlation of the Lower Cretaceous formations between the SW Barents Sea and Svalbard. (A) Palaeogeographic map of the NW-sourced intrashelf platform system in the Barremian and lobe nomenclature (modified from Midtkandal et al., 2019a) with the study area outlined by the black box. (B) The stratigraphic framework of the Lower Cretaceous in the SW Barents Sea (Fingerdjupet Subbasin, Hoop and Bjarmeland Platform) and Svalbard (Kong Karls land and Spitsbergen) based on Smelror et al. (1998), Dallmann (1999) and Smith et al. (1976). The chronostratigraphic ages for the Barremian-Aptian boundary are from Cohen et al. (2013) and Midtkandal et al. (2016).

from the northeast (Grundvåg et al., 2017; Marín et al., 2017; Midtkandal et al., 2019a). In accordance with Midtkandal et al. (2019a), the NW-sourced system is divided into lobes NW1 and NW2, labelled according to descending relative ages meaning NW1 is oldest (evidence shown in this study). The NE-sourced lobes are labelled NE1-NE5, from youngest to oldest.

\section{Data and methods}

\section{Database}

The seismic data utilised in this study comprise wide azimuth 2D (2.5D) and 3D high-resolution P-Cable and $3 \mathrm{D}$ conventional seismic data covering parts of the Hoop area including the central distal parts of lobe NW2 (Figs. 1B \& 2A). The main conventional seismic dataset $\left(4392 \mathrm{~km}^{2}\right)$ is a part of the Hoop Fault Complex 3D cube with bin size 18.75 X $12.5 \mathrm{~m}$ (Fig. 1B). Two narrow 3D high-resolution P-Cable seismic cubes (Area C: 14 $\mathrm{km}^{2}$ and Area D: $12 \mathrm{~km}^{2}$ ) with bin size $6.25 \times 6.25 \mathrm{~m}$, and selected 2.5D P-Cable lines with trace spacing 12.5 $\mathrm{m}$ are also included in the database. In addition, a set of $2 \mathrm{D}$ conventional seismic lines were used to establish ties to the adjacent Fingerdjupet Subbasin (Serck et al., 2017). The P-Cable data have a very high near-offset trace density, 3-6 $\mathrm{m}$ native bin size, and a uniform trace distribution in both the inline and the crossline directions, compared with conventional 3D seismic with typical bin size $12-50 \mathrm{~m}$ and down to $6.25 \mathrm{~m}$ in inline direction (Planke et al., 2004, 2009; Planke \& Berndt,
2007; Lebedeva-Ivanova et al., 2018). The high spatial and temporal resolution of the data makes it possible to clearly image numerous sub-horizontal and dipping reflections not detectable in conventional 2D or 3D data.

The power spectrum (Electronic Supplement 1) shows that the conventional seismic data have dominant frequencies between 20 and $60 \mathrm{~Hz}$, while the P-Cable data have frequencies up to at least $200 \mathrm{~Hz}$ at the $-20 \mathrm{~dB}$ level. The power spectrum represents the waves that were extracted from the seismic data used in the 1D synthetic seismic modelling (see synthetic seismic traces in Fig. 3). The different frequencies have considerable impact on the seismic resolution. Since the high-resolution P-Cable data have a significantly higher frequency range, hence shorter wavelengths, they have higher resolution than conventional seismic data. Thus, the conventional seismic data typically have a vertical resolution, corresponding to a quarter of the wavelength (Yilmaz, 2001; Herron, 2011), of 15-25 m, while the P-Cable seismic data have a vertical resolution in the range of 3-7 m (Table in Electronic Supplement 1) in the shallow subsurface. This difference in seismic resolution is clearly visible in Fig. 3 showing a tie between the two seismic data types at well 7324/2-1 (Apollo; Fig. 1B). The well data and the synthetic traces, created from petrophysical parameters (sonic and density) and waves extracted from the seismic, correspond well with the recorded seismic responses (Fig. 3).

Well data, including geophysical logs and age control based on biostratigraphic information (A. Ryseth, pers. comm., 2017), were obtained from two exploration wells located $15 \mathrm{~km}$ apart within the main study area (Apollo: 


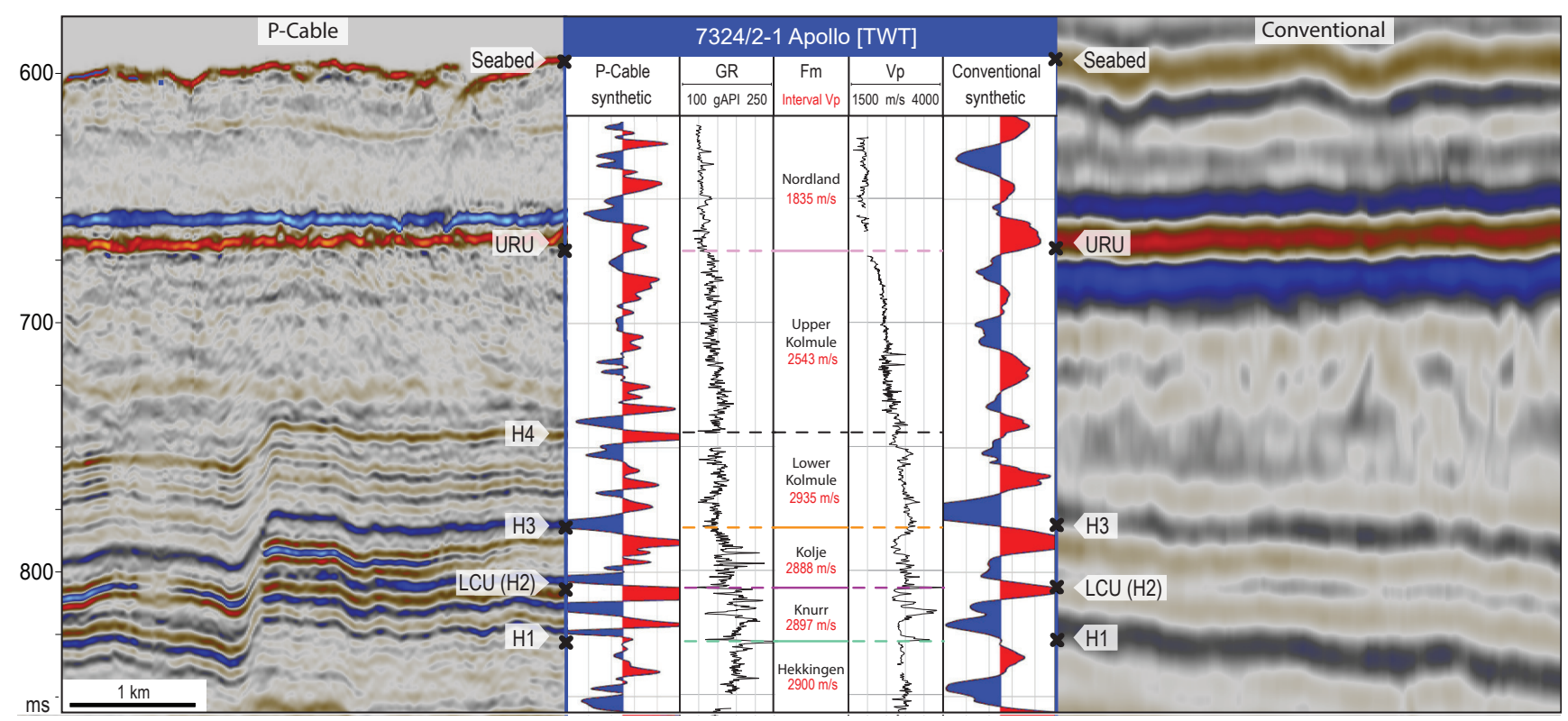

Figure 3. RComparison of P-Cable (left) and conventional seismic data (right) at the Apollo well. The well panel dividing the seismic data includes gamma ray (GR) and P-wave velocity (Vp). In addition, modelled synthetic traces for each seismic data type - P-Cable (left) and conventional data (right). The formations and their respective interval velocities are shown in the middle panel. The formation boundaries are marked in the well data. The corresponding synthetic traces and their respective reflections in the seismic data are interpreted based on the well data. Abbreviations: URU Upper Regional Unconformity, LCU - Lower Cretaceous Unconformity. Seismic data courtesy of TGS, WGPS and VBPR.

7324/2-1; Atlantis: 7325/1-1; Fig. 1B). In addition, information from the shallow IKU corehole 7425/9U-1 (Fig. 1B) penetrating the Klippfisk Formation was used (Århus et al., 1990; Århus, 1991; Smelror et al., 1998). Ties were also established to wells in the adjacent Fingerdjupet Subbasin, in particular to well 7321/7-1 (Serck et al., 2017). Gamma logs from two additional recent wells (7324/3-1 and 7325/4-1; Fig. 1B) were also included for correlations and lithology determination. The 7324/3-1 well is the first well to penetrate the NW2 lobe.

\section{Methods}

The formation boundaries were determined in the Apollo and Atlantis wells based on typical log responses from the type and reference well of the lithostratigraphic units (NPD, 2017). Well log data such as gamma ray, sonic (both P- and S-waves), neutron, density, and photoelectric factor (PEF) were used for lithology determination and seismic-to-well ties. The synthetic traces in Fig. 3 were produced by $1 \mathrm{D}$ seismic modelling based on a reflectivity log convolved with the wavelets that were extracted from the two types of seismic data. The reflectivity log is generated from reflection coefficients, which are calculated based on the sonic and density logs. For missing intervals, a pseudo-density log was estimated based on the sonic velocity log. Comparing the synthetic trace with the real seismic at the well location improves the horizon picking and the correctness and resolution of formations of interest (Mondol, 2015).
Five horizons were mapped out in the seismic data based on the seismic-to-well tie (Fig. 3). The mapping of the reflections corresponding to the formation boundaries was first done on composite lines between the Apollo and Atlantis wells. All 2.5D P-Cable lines in the main study area were mapped out and ties were established to the two 3D P-Cable cubes (Fig. 1B). For the conventional seismic 3D cube, every 10th inline and 50th crossline were interpreted with $2 \mathrm{D}$ and manual interpretation tools before applying $3 \mathrm{D}$ auto-tracking. Time-structure maps of the seismic horizons and thickness maps for selected units were made from the conventional 3D data, which cover the main study area, due to the narrow extent of the 3D P-Cable cubes. Vertical and horizontal sections in the conventional and high-resolution seismic data were used for displaying important geological features (e.g., clinoforms and faults).

To restore the clinoform architectures, flattening was performed on the downlap surface at the base of the prograding unit, on the assumption that this surface was relatively flat at the arrival time of the NW-sourced intrashelf platform lobes (Midtkandal \& Nystuen, 2009). Flattening on other surfaces was also performed to study thickness variations and geometries in relation to faulting, but the faulting and erosion of younger strata makes uniform flattening on a presumed horizontal surface above the studied strata impossible. Finally, the amount of Early Cretaceous extension was estimated by calculating the cumulative heave of the mapped faults along a regional seismic line going from the Fingerdjupet Subbasin to the Hoop area. The horizontal displacement 
on each shallow fault, which is well imaged by the seismic data, was added together to obtain an extension estimate. This approach provides a good approximation for the true extension across the area (Sclater \& Celerier, 1989).

\section{Results}

\section{Seismic stratigraphy and well ties}

The seismic stratigraphic framework of this study is summarised in Figure 4 for both the high-resolution and the conventional seismic data at the Apollo well. The seismic panels within the 740-830 ms interval clearly demonstrate the different vertical resolutions of the two seismic data types. In the high-resolution data about 17 reflections can be identified within this interval, in contrast to the 7 reflections in the conventional seismic data. The high-resolution P-Cable data thus add important details to our understanding of the Lower Cretaceous depositional architectures and basin evolution.

The Lower Cretaceous Knurr, Kolje and Kolmule formations are bounded by four main horizons; H1, H2, $\mathrm{H} 3$ and URU in successive order (Fig. 4). H1 represents the boundary between the Knurr and Hekkingen formations at the Jurassic-Cretaceous transition. H2 is located near Base Kolje, hence the horizon corresponds to the Hauterivian-Barremian boundary termed the Lower Cretaceous Unconformity (LCU) by Midtkandal et al. (2019a). This horizon will be referred to as LCU throughout the paper. The LCU is commonly termed Base Cretaceous Unconformity (BCU) in regional mapping of the southwestern Barents Sea platform areas in conventional seismic data. The true Base Cretaceous

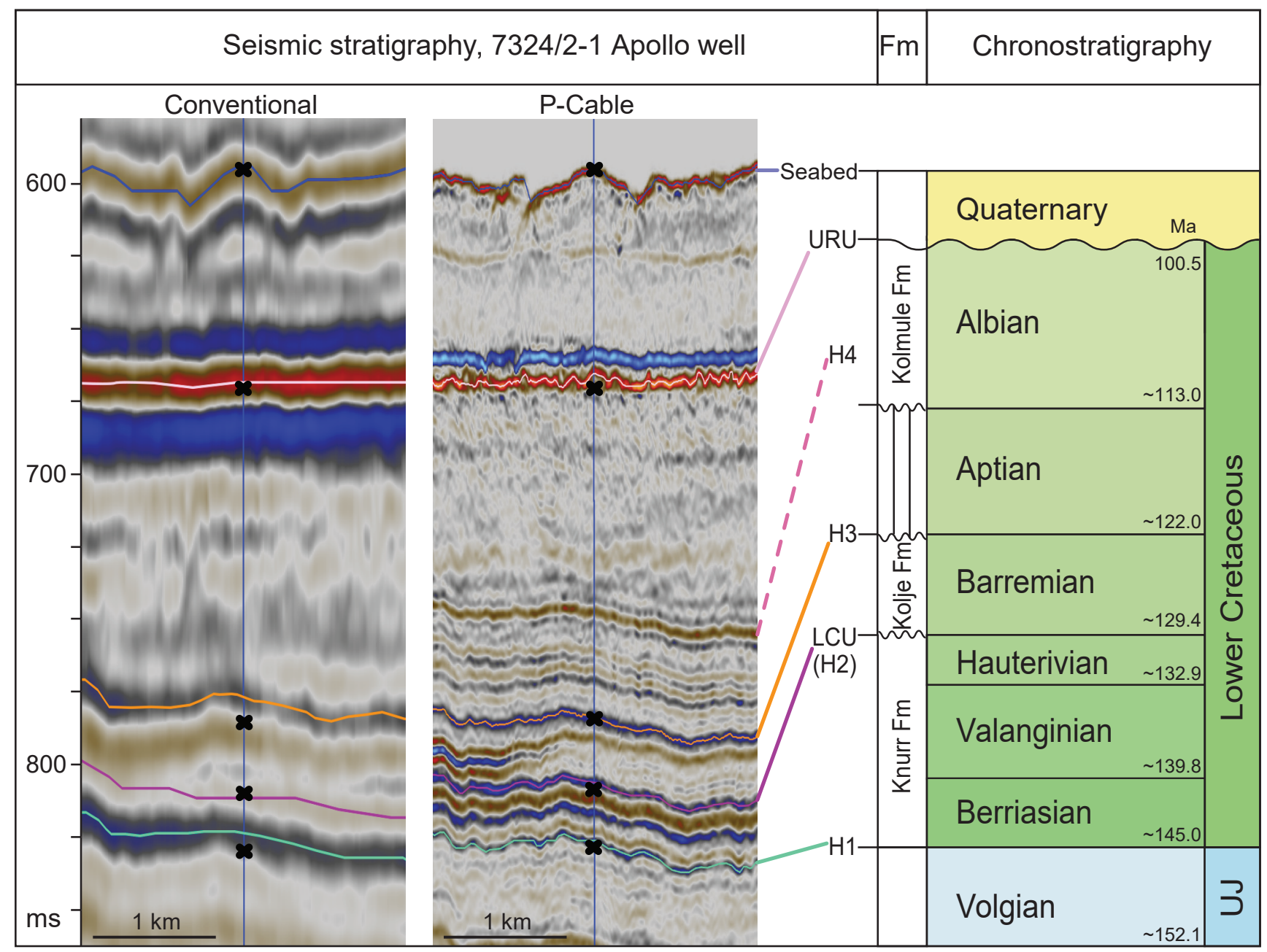

Figure 4. Seismic stratigraphic framework for both P-Cable and conventional seismic data tied to 7324/2-1 (Apollo). The traced reflections in this study are correlated between the seismic panels and the chronostratigraphy, and set the boundaries for the Knurr, Kolje and Kolmule formations. The Kolmule is furthermore divided into two seismic units by the seismic reflection $\mathrm{H} 4$ in the high-resolution data. A hiatus in Aptian is marked in the well. Chronostratigraphic ages from Cohen et al. (2013), in addition to Midtkandal et al. (2016) for the Barremian-Aptian boundary. Note the different resolutions of the two seismic datasets. Abbreviations: URU - Upper Regional Unconformity, Fm - Formation, LCU - Lower Cretaceous Unconformity, UJ - Upper Jurassic. Seismic data courtesy of TGS, WGPS and VBPR. 
(BC) is located below the Knurr unit at the transition to the Hekkingen Formation (H1). The closely spaced Hauterivian-Barremian boundary (H2/LCU) and Jurassic-Cretaceous boundary $(\mathrm{H} 1 / \mathrm{BC})$ is not possible to separate in conventional seismic data. In the highresolution data, on the other hand, the about $30 \mathrm{~m}$-thick condensed Knurr Formation consists of 5-6 reflections and can be interpreted as a separate seismic unit with varying lithology (Fig. 4).

$\mathrm{H} 3$ is located at the base of the Kolmule Formation. In the Apollo well it represents a hiatus since no sediments of Aptian age are reported (A. Ryseth, pers. comm., 2017). Therefore, a Barremian age for the present Kolje Formation and an Albian age for the lower Kolmule Formation could be determined in the well. The Kolmule Formation is divided into two distinct units by $\mathrm{H} 4$ in the high-resolution data. A lower part with several, strong, continuous seismic reflections and an upper more transparent part (Figs. 3 \& 4). The top of the Lower Cretaceous strata (Kolmule Formation) is called the Upper Regional Unconformity (URU) and represents a large hiatus at the base of a thin cover of Quaternary deposits.

The seismic horizons are continuous and easy to trace between the Apollo and Atlantis wells in the composite 2.5D P-Cable line in Fig. 5, and throughout most of the study area. In some parts, H3 is difficult to trace. The H1-LCU interval has a very consistent reflection pattern along the line and shows a minor thickness increase from the Apollo to the Atlantis well (Fig. 5). The LCUH3 sequence, corresponding to the Kolje Formation, also increases in thickness from the Apollo to the Atlantis well, while the $\mathrm{H} 3-\mathrm{H} 4$ interval thickens in the opposite direction. Reflection terminations show that $\mathrm{H} 3$ represents an unconformity (Fig. 5), likely associated with the Aptian hiatus reported in the Apollo well.

The brief lithology determination done in this study based on well log data (Electronic Supplement 2) indicates mostly fine-grained sediments within the Lower Cretaceous succession. A generally medium-high gamma-ray response, positive separation in neutrondensity log and medium PEF-values are documented, all indicative of fine-grained sediments. In contrast, the Jurassic Stø Formation sandstones are characterised by a low gamma-ray response and a negative separation in the neutron-density log. An intra-Knurr layer (marked by an arrow in Electronic Supplement 2) has a distinct low gamma-ray and high-velocity response indicating more coarse-grained sediments. The high-velocity intraKnurr layer has a higher PEF response, about 5 barns/ electron, and together with the density value of $\sim 2.7 \mathrm{~g} /$ $\mathrm{cm}^{3}$ it may represent a limestone. The mean PEF, density and neutron values for the Kolje Formation in the Apollo well were plotted into a diagram for typical log responses of various lithologies by Mondol (2015), where they all fall within the shale interval.

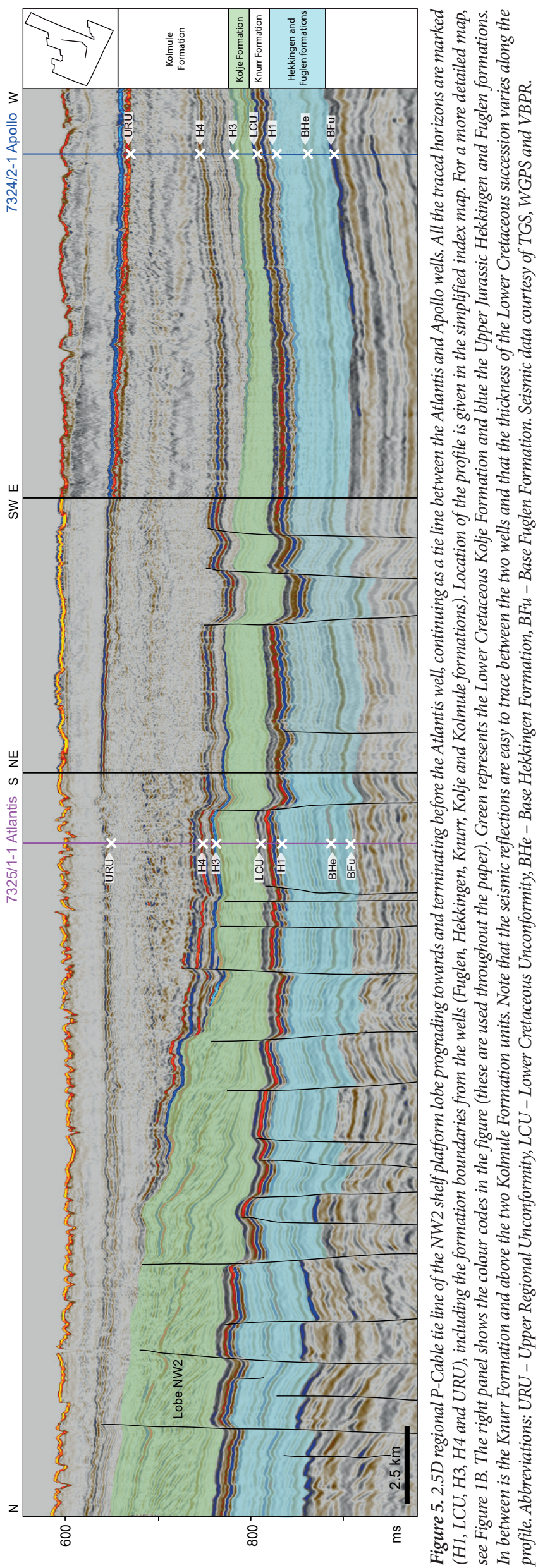



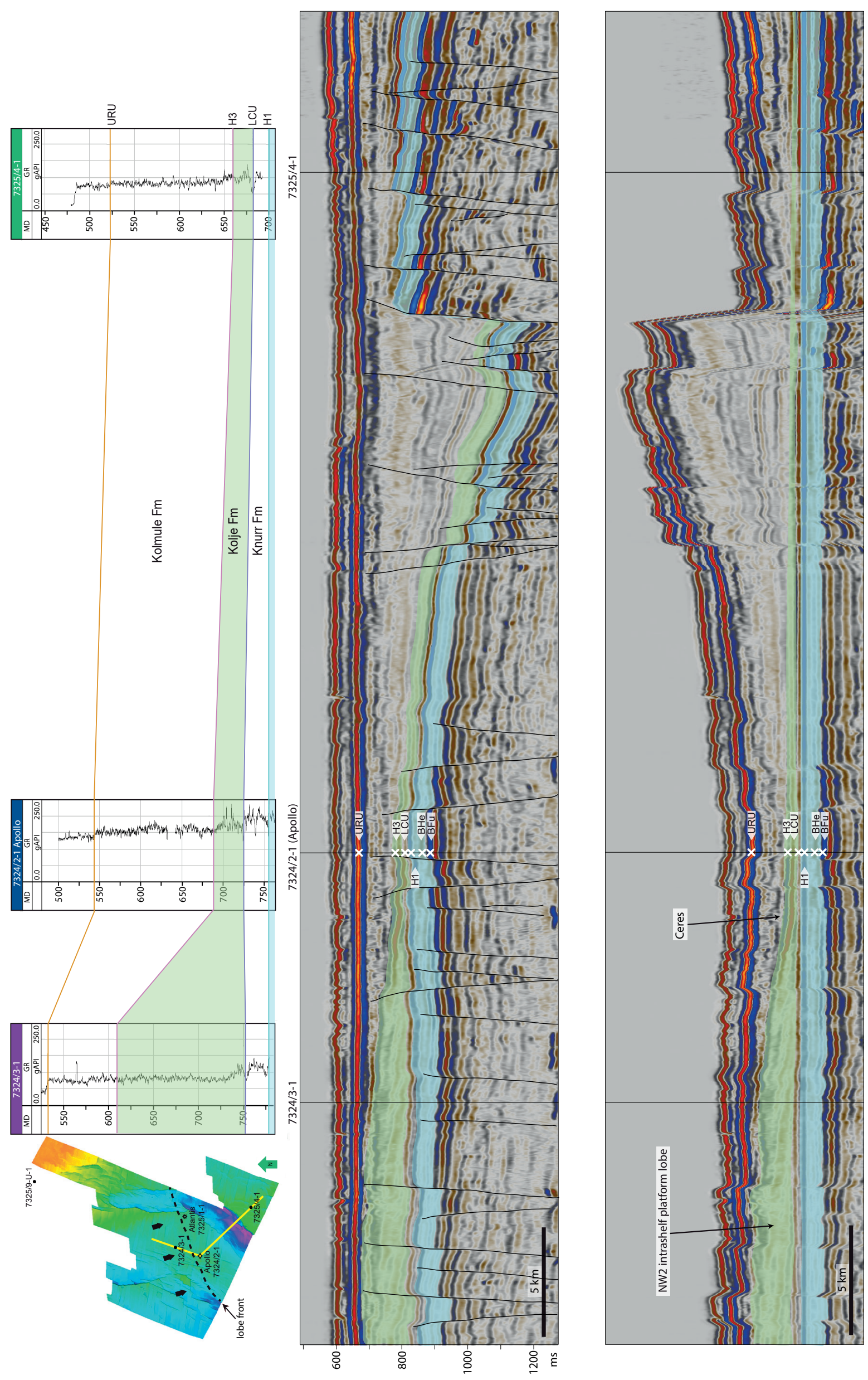

है ฐิ

एँ

इ

ट. ङ

눈

2
3
3

पू

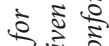

.

过 范

जิ

จ

8 ०

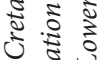

ป

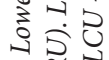

\& 5

ᄒั

$\Leftrightarrow 0$

इन चा

i $\bar{I}$

ई

究 ?

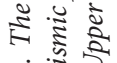

竎

इ $\frac{2}{2}$

I. $5: 5$

थै

उ चे ईँ

T $\frac{2}{2} \frac{\pi}{2}$

मे के गे

กิ

त ह ह

$\frac{1}{m} \equiv$

तี

₹

$\frac{\pi}{2} \frac{5}{2}$

ปे ปे

कू इड उ०

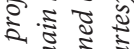

.

जै

इ 30

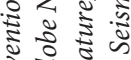

दे है $\frac{2}{2}$.

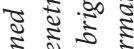

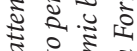

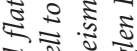

ह छ

चु

ปี

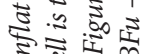

2 ₹

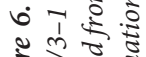

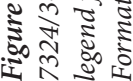


The gamma-ray log in Apollo well (7324/2-1) is correlated to the two recent (and not yet released) wells 7324/3-1 and 7325/4-1 (Fig. 6; see Fig. 1 for locations). Both wells have lower gamma-ray values for the Kolje Formation than in the Apollo well, indicating coarser lithologies but still rather fine-grained. Well 7324/3-1 is the first one drilled through lobe NW2 in the Hoop area and it shows that the distal part of the NW2 lobe is characterised by a gamma-ray response of $\sim 75$ gAPI reflecting a shaly sand to sandy shale lithology.

\section{Barremian intrashelf platform lobes}

The Barremian intrashelf platform deposits, divided into lobe NW1 and NW2 by Midtkandal et al. (2019a), are imaged in the high-resolution (Fig. 5; Electronic Supplement 3) and conventional seismic data (Figs. 6 \& $7)$. In the high-resolution seismic profile in Electronic Supplement 3, lobe NW2 is seen to onlap lobe NW1, revealing that NW1 developed earlier than lobe NW2. Lobe NW2 prograded towards SE-SSE and terminated before reaching the Atlantis and Apollo wells (Figs. 5, 6 \& 7). The prograding unit is offset by younger faulting (e.g., Figs. 5, 6 \& 7) so to restore this unit with its characteristic clinoforms restoration by flattening the downlap surface, LCU, is necessary. The flattening removes the effects of younger faulting, making it possible to study the clinoform geometries in greater detail (Figs. 6, 7 \& 8).

The N-S seismic line of the regional combined 2.5D high-resolution profile in Figure 5, north of Atlantis well, is flattened on LCU in Figure 8A and compared to a similar flattened profile extracted from the $3 \mathrm{D}$ conventional seismic data (Fig. 8C). In addition, the main clinoform surfaces of lobe NW2 are depicted in line drawings for each dataset (Fig. 8B, D). The highresolution data reveal that the lobe NW2 clinothems comprise clinoforms at two scales, unlike in the conventional seismic data where only the large-scale clinoforms are imaged (Fig. 8). Internally, lobe NW2 consists of a series of well-defined clinothems bounded by moderately steep clinoforms that downlap onto, or near, the LCU reflection above the Knurr/Klippfisk formations. The clinothems exhibit a well-developed topset-foreset-bottomset style.

The large-scale clinoforms are the most readily recognised reflection pattern within lobe NW2 and are well expressed on the conventional seismic sections (Figs. 6, 7 \& 8C, D), as applied by Dimitriou (2014), Marín et al. (2017), Grundvåg et al. (2017) and Midtkandal et al. (2019a). The topset-foreset-bottomset pattern spans the entire thickness of lobe NW2 $(\sim 150$ 200 ms; Figs. 6, 7 \& 8). Using an average seismic velocity of $\sim 2900 \mathrm{~m} / \mathrm{s}$ as found for the Kolje Formation in the Apollo and Atlantis wells, the present-day observed thickness of lobe NW2 is up to $300 \mathrm{~m}$. Based on depth- converted heights of the large-scale clinoforms in Figure 8 , the average foreset dip basinward has been estimated to $\sim 1.85^{\circ}$, but typical dip angles range between about $1.3^{\circ}$ and $2.4^{\circ}$. In a complementary study, Midtkandal et al. (2019b) present and discuss detailed clinoform/ clinothem geometries of lobe NW2 where estimated dips and heights are corrected for compaction and isostatic effects during burial. The effects of more than $2000 \mathrm{~m}$ of Cenozoic erosion are also taken into account. The large-scale clinothem topsets commonly merge into indistinguishable reflections towards the northwestern part of the study area. Similarly, the bottomsets merge into subparallel to parallel reflections near their distal terminations toward southeast giving the appearance of downlap onto the LCU or a stratigraphic level closely above it.

The small-scale clinoforms are imaged intermittently between the aforementioned large-scale clinoforms. They form sets of steeply dipping reflections that are contained as fully or partially developed, topset-foresetbottomset clinoforms (blue in Fig. 8). These successions of small-scale clinothems make up the interiors of the larger-scale clinothems described above. These sigmoidal and parallel oblique clinoforms, which likely reflect some lateral lithology variations, are largely unresolvable in conventional seismic sections, but are clearly visible in high-resolution seismic (Fig. 8). The small-scale clinoforms are markedly steeper than the large-scale clinoforms, with dips in the range from 4.4 to $>10^{\circ}$ and typical heights of about $100 \mathrm{~m}$ (Midtkandal et al., 2019b).

The front of the intrashelf platform lobe NW2 was mapped in detail using both the conventional and the high-resolution seismic data. First, the conventional seismic data were screened in order to map the pinchouts of the prograding system. Second, the mapping was fine-tuned in areas with high-resolution data where the front can be mapped out more accurately due to higher resolution (selected profiles in Figs. $5 \& 8$ ). In front of lobe NW2, a significant brightening in the seismic is observed in both the high-resolution (Figs. 5 $\& 8$ ) and the conventional (Figs. 6, $7 \& 8$ ) seismic data. The brightening, termed Ceres in Corseri et al. (2018), is also associated with a strong resistive anomaly from 3D inversion of CSEM data (Baltar \& Barker, 2017). It is interpreted as an Aptian submarine channel system developed in front of lobe NW2 by Corseri et al. (2018).

The NW2 lobe termination line is marked in Figure 9 on top of the $\mathrm{H} 1$ time-structure map and on the thickness map of the sequence $\mathrm{H} 1-\mathrm{H} 3$, corresponding to the condensed Knurr Formation and the Kolje Formation in the $3 \mathrm{D}$ conventional seismic data. The $\mathrm{H} 1$ time-structure map shows the main structural elements within the study area, with characteristic fault patterns that will be described and discussed below. The time-slices taken within the clinoform interval, in Area C (775 ms) and Area D $(720 \mathrm{~ms})$, provide information on the clinoform 


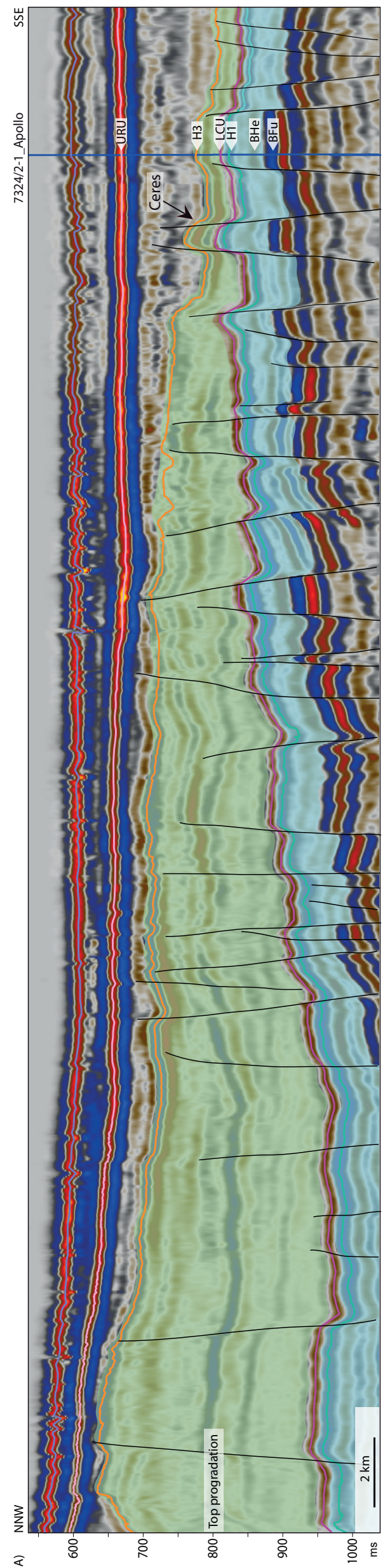

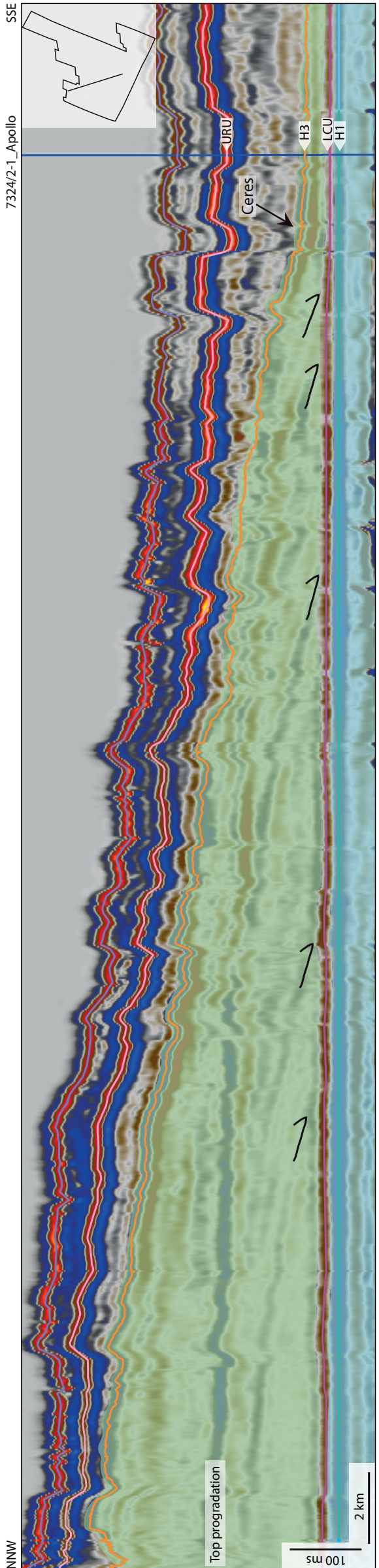

๓

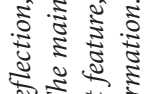

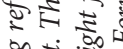

章专

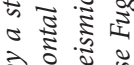

उ. के

उँ

ํำ

3 ㄷำ

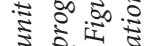

उ

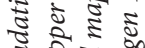

ㅇำ

올

₹

के

क्षे

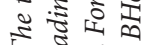

से 50

₹

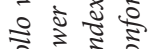

क्षे 한

논

오.

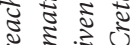

도.

इ용

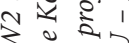

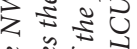

จำ

के

ธิ ซิ

कूष

단

- 폰

क्ष

के

क्षेड

ํㅠㄹำ

पर

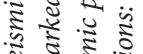

व

के के के

है

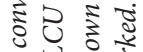

ब주 कह

ए है है क

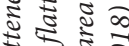

당

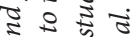

उ

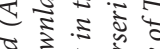

ฐ웡 डे के

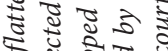

$5 \%$ 용

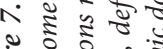

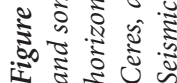




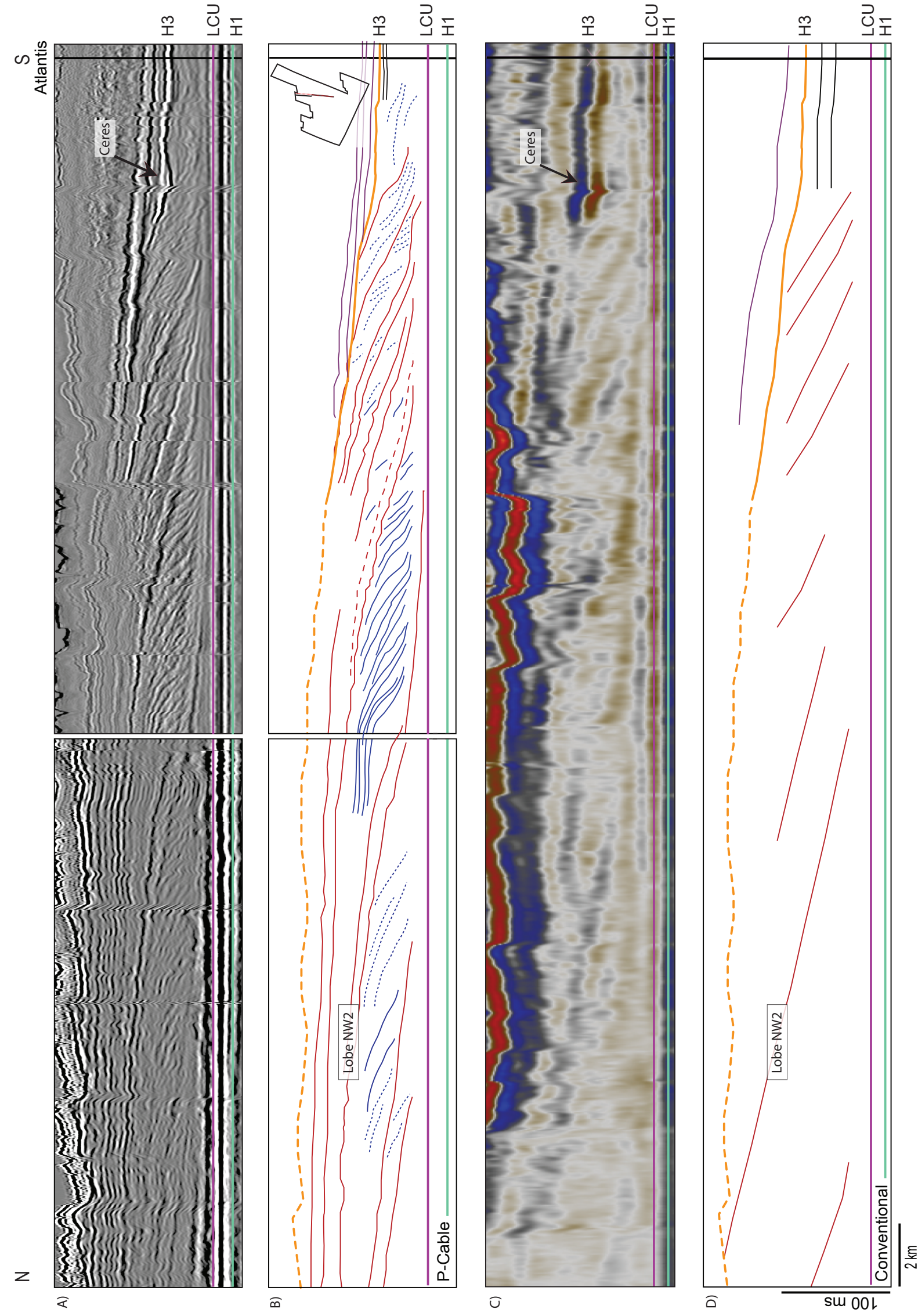

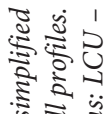

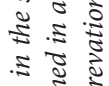

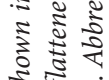

क्या

苍热

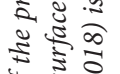

s.

क्षे

일

施

(ิ)

से है

$\approx \frac{2}{2}$

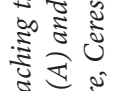

焉

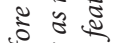

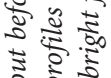

है है

है

है ₹

今ิ

है ह 흐

을

전

옿

bo

है

공

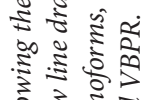

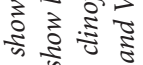

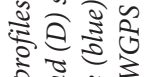

혼 3

흘

कू क्ष

(2) क्षे

․ㅗㅇ

ะ :

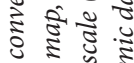

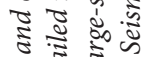

这弯

ฐั้

क 웡

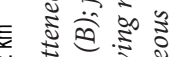

这.

$\infty$ द्वे टे

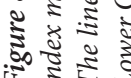


orientation in lobe NW2 (Fig. 9). This reveals a SSEdirected progradation (black arrows).

The Barremian strata thin significantly toward southeast (Fig. 9), which reflects the prograding lobe system that came in from the north-northwest and terminated before reaching the Apollo and Atlantis well locations. The map shows some line effects in the northwestern part which are related to uncertain correlations across faults and chaotic reflections. In the northwesternmost part of the area, H3 is eroded by URU (Fig. 9). Here, the seismic sequence corresponding to the Kolje Formation is at least $300-350 \mathrm{~m}$ thick, including both the NW2 lobe and the overlying horizontally layered part of the formation. It gradually thins distally towards the lobe front and the position of the Apollo and Atlantis wells (Figs. 6, 7 \& 8).
The LCU-H3 seismic sequence, corresponding to the Kolje Formation, commonly comprises two characteristic units, a lower part with clinoforms (lobe NW2) and an upper part with nearly parallel reflections, separated by a strong reflection (Top progradation in Fig. 7). This topset reflection is largely parallel to the LCU horizon used for flattening, which supports our assumption that the regional downlap surface was relatively flat. The same two-fold division of the Kolje Formation is observed in the Fingerdjupet Subbasin (Serck et al., 2017) where the formation is much thicker compared to the Hoop area (Fig. 10). Wells in the Fingerdjupet Subbasin (e.g., 7321/7-1) confirm the Barremian age of the Kolje Formation including the prograding unit that is part of the NW2 lobe.

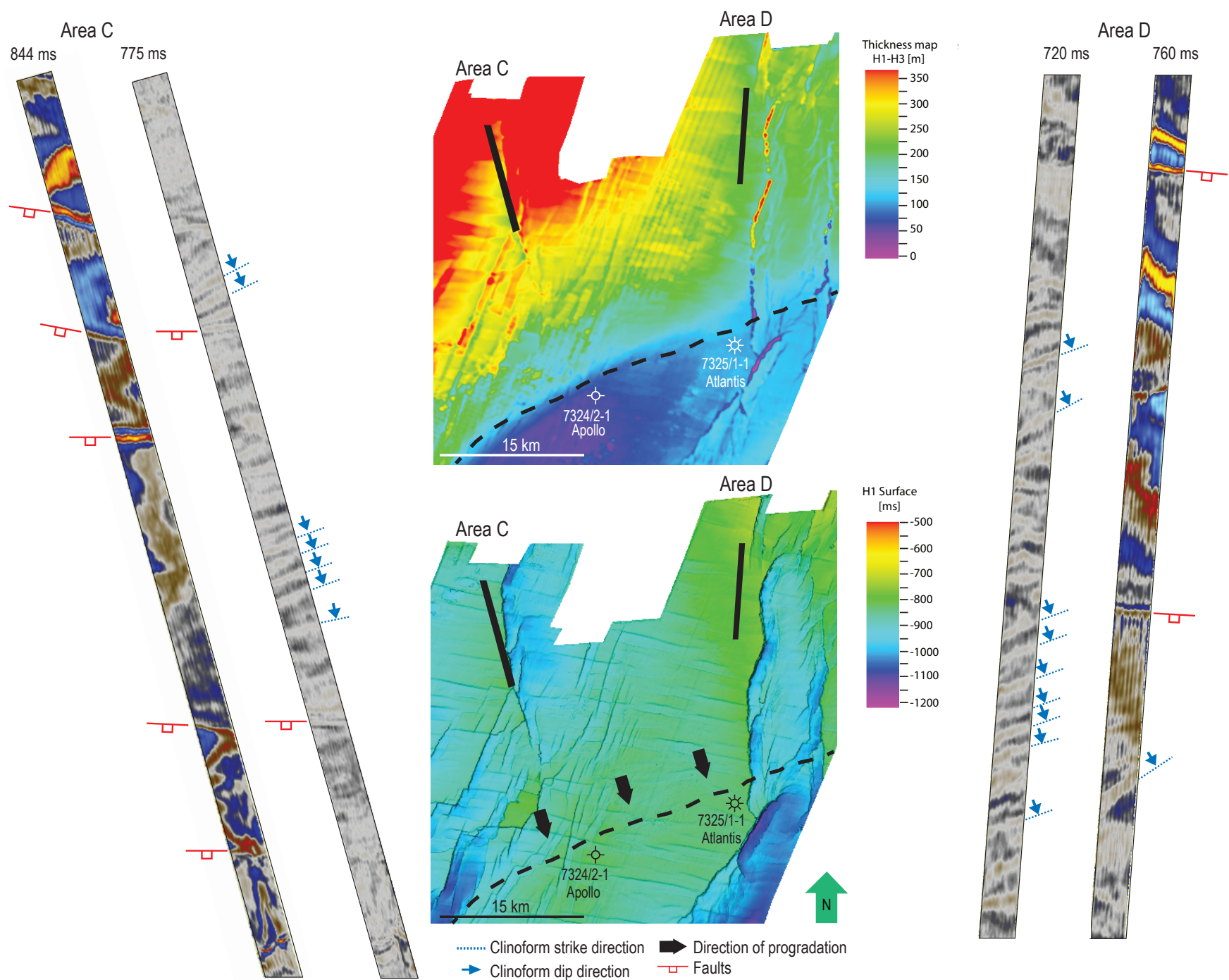

Figure 9. Time-slices of 3D P-Cable data in Area C (left) and Area D (right) with location on the H1 surface and the thickness map of seismic sequence corresponding to the Kolje Formation and the condensed Knurr Formation (H1-H3). The 775 ms (Area C) and 720 ms (Area D) time-slices are taken within the clinoform interval, while $844 \mathrm{~ms}$ and $760 \mathrm{~ms}$ are time-slices representing areas highly affected by faults. The strike trend (dashed blue line) and dip direction (blue arrow) of the clinoforms were identified by the time-slices. The dashed black line marks the front of the prograding shelf platform system in the study area. The red fault symbols represent the faults in the area and the black arrows illustrate the overall direction of progradation. Seismic data courtesy of TGS, VBPR and WGPS. 

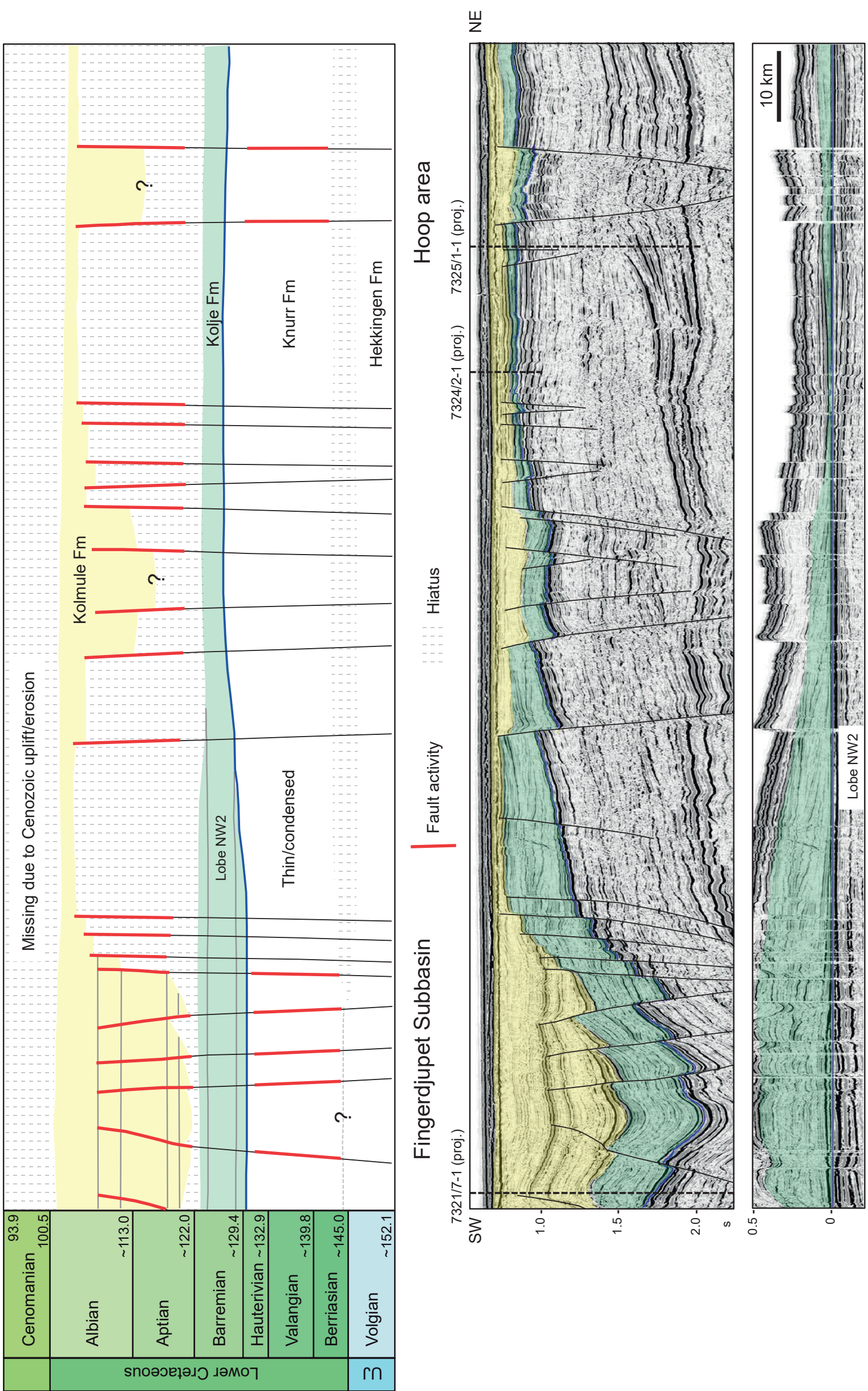

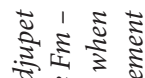

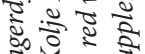

政

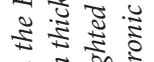

도용

ऊิ 3

วิ

ฐ

ฟ

을

उं है है

उ

ङ

है है क्षे

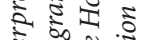

ป : ङ

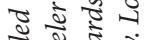

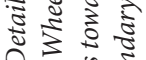

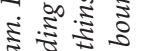

ริำ ㅎำ

के है

ชั :

5 5 ह

웡

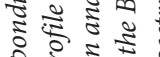

के ₹

흔 홍 $\frac{1}{6}$

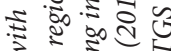

ह इ वे

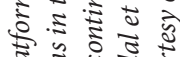

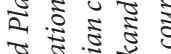

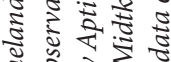

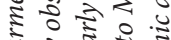

के

₹

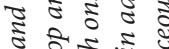

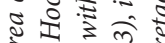

ธะ ㅇำ

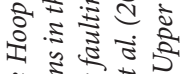

₹

:

$\approx 200$

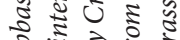

के के

范范

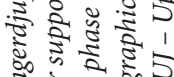

के क्षे

₹

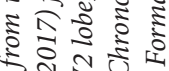

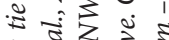

参吉志兘

นั้

0

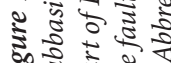



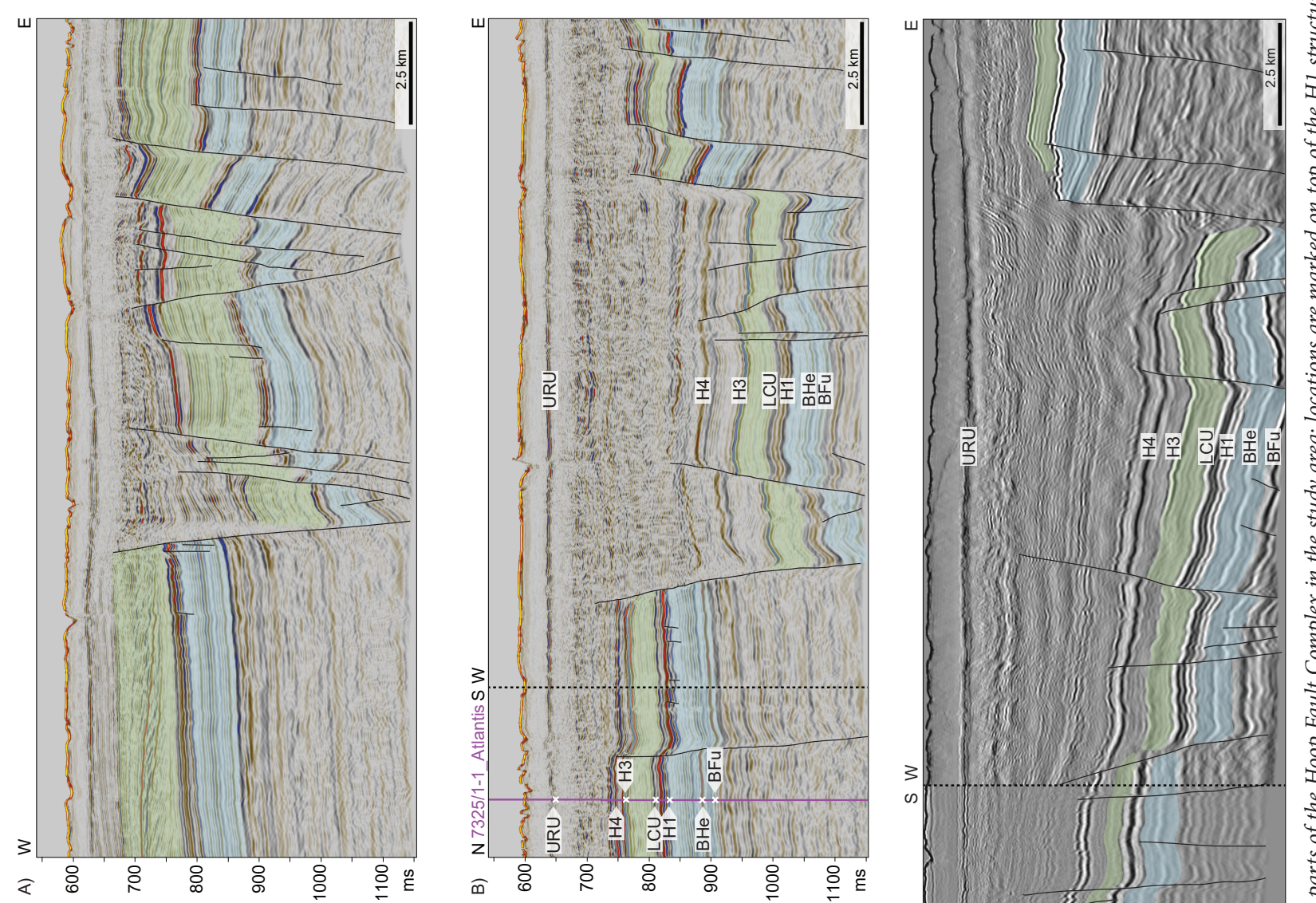

इ)

ㅎํㄹำ

늉 की

I

इ

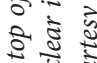

ธิ

ำ

के

इ क

司赔

ปั

डิ के के

गे इ इ

के

$\therefore$ 은

अ है है

हิ

के स

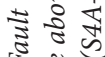

证

क्षे

कू क

के
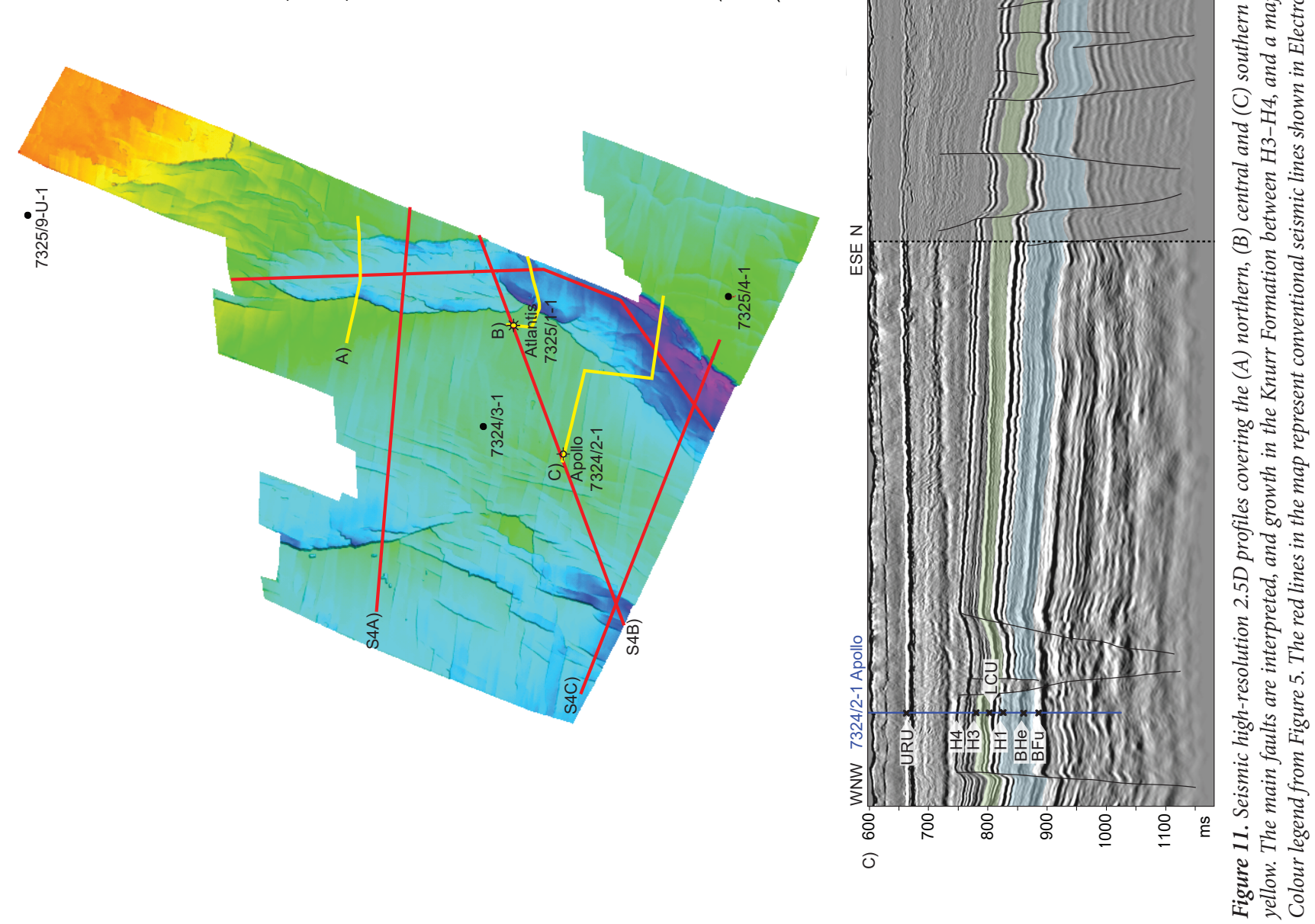


\section{Early Cretaceous faulting}

The most prominent structural feature in the Hoop area is a NE-SW- to N-S-trending segmented graben system revealed on the H1 time-structure map (Fig. 9). In addition, the area is cross-cut by a set of $\mathrm{E}-\mathrm{W}$-trending faults (Collanega et al., 2017).

The main phase of Early Cretaceous faulting postdates the arrival of the Barremian NW-sourced lobe. Therefore, the effects of these faults have to be removed to restore the clinoform geometries as presented above. Both the high-resolution seismic data (Fig. 11) and the conventional seismic (Fig. 6, Electronic Supplement 4) show growth sequences within the graben structural elements above the seismic unit corresponding to lobe NW2 within the Kolje Formation. The three, highresolution, seismic profiles in Figure 11 illustrate along-strike variations in the rift architecture of the main graben system. The southern profile across the NW-SE-trending graben segment (Fig. 11C) shows a half-graben geometry with the main boundary fault on the southeastern side. The northern profile (Fig. 11A) crosses a N-S-trending half-graben structure with the main boundary fault on the western side. The central profile (Fig. 11B) reveals a more symmetric graben structure close to the intersection between the NESW- and N-S-trending graben segments. Note that the eastern boundary fault is located outside the coverage of the 3D seismic data in the central profile. The main boundary faults typically have throws of $200-250 \mathrm{~ms}$, corresponding to $290-360 \mathrm{~m}$.

Detailed interpretations and ties to the nearby wells indicate an Aptian?-mid Albian age of the main phase of faulting (e.g., Figs. 6, 10 \& 11). Faulting was likely initiated in the Aptian but the hiatus/condensed section makes it difficult to constrain the exact onset of faulting in the Hoop area. The faults appear to terminate within the middle-upper Kolmule Formation but it is difficult to map out this in detail because of the transparent character of this interval, in addition to the younger (Cenozoic) erosion associated with the Upper Regional Unconformity (URU). A more complete Lower Cretaceous stratigraphy is preserved in the neighbouring Fingerdjupet Subbasin, with evidence of a more intense phase of faulting that can be dated to mainly Aptian age, with some fault activity extending into the Albian (Fig. 10; Serck et al., 2017).

The high-resolution data also reveal a phase of minor faulting and growth during deposition of the Knurr Formation in the Berriasian-Hauterivian (Fig. 11). This growth is largest within the main graben segment associated with the Hoop Fault Complex. Here, the Knurr Formation attains a thickness of up to $65 \mathrm{~m}$ which is twice its thickness in the Apollo and Atlantis wells (e.g., Figs. 4, 5 \& 11).
The E-W faults seen in the time-structure map in Figure 9 appear to have initiated prior to the Cretaceous but they also have some impact on the Lower Cretaceous units. This is reflected in the fault throw, largest in the Jurassic and decreasing towards the Cretaceous. The fault orientation can also be studied by looking at timeslices. Time-slices taken around the H1-LCU sequence highlight the faulting in the area (Fig. 9), deepest in Area C (844 ms) compared to Area D $(760 \mathrm{~ms})$, and document a dominating E-W trend. The magnitude of Early Cretaceous extension across the Fingerdjupet-Hoop area has been estimated to $9-10 \mathrm{~km}$ based on the cumulative heave measured along the regional profile in Figure 10. Regional implications of this extension will be discussed below.

\section{Discussion}

\section{Base Cretaceous, Lower Cretaceous Unconformity and the lowermost Cretaceous Knurr Formation}

The detailed work on the well data shows that the Knurr Formation is not only associated with acoustic impedance contrasts at its top and base, but also that within this thin condensed unit there are significant variations in seismic response (Figs. $3 \& 4$ ). The highresolution seismic data detect and resolve many of these, whereas in the conventional seismic data the entire Knurr Formation corresponds to a composite peak and trough (Figs. $3 \& 4$ ). The resolution limitations in the conventional seismic data therefore make it difficult to determine the exact pick for a Base Cretaceous (BC) interface. For the same reason, Marín et al. (2017) and Grundvåg et al. (2017) were not able to distinguish between their $\mathrm{S} 0$ and $\mathrm{S} 1$ sequences, corresponding to the Knurr Formation, in the Hoop area. The high-resolution seismic data also record small, fault-related, thickness variations within the Knurr Formation (Fig. 11). Minor faulting during deposition of the Knurr Formation is also observed within the Fingerdjupet Subbasin (Fig. 10; Serck et al., 2017). The same interval corresponds to the thin limestone unit defined as the Klippfisk Formation on the Bjarmeland Platform (Smelror et al., 1998). The limestone was penetrated by the shallow IKU corehole 7425/9-U-1 located close to the northernmost part of the study area (Fig. 1B), so the transition between the Knurr and Klippfisk formations occurs within the study area.

The LCU formed the downlap surface of the intrashelf platform lobes prograding from the northwest. To understand the Early Cretaceous subsidence history of the Hoop and surrounding platform areas it is important to estimate the water depths in which the Knurr and Klippfisk formations were deposited. Were they deposited under considerable water depths but 
became condensed due to lack of clastic input or were they, in particular the limestones of the Klippfisk Formation, deposited in shallow waters? The latter would imply rapid subsidence at the HauterivianBarremian transition to create the water depths inferred from the intrashelf platform clinoform geometries. Typical clinoform heights were restored to $250-300 \mathrm{~m}$ by Midtkandal et al. (2019b). In addition, we have to take into account the water depths on the shallow platform at the top of the intrashelf clinoforms. Thus, the depths down to the deep basin floor on the shelf may have been up to $400-500 \mathrm{~m}$. The minor faulting observed within the Knurr Formation along the Hoop Fault Complex (Fig. 11) and in the Fingerdjupet Subbasin (Fig. 10; Serck et al., 2017) may have contributed to the subsidence.

\section{Barremian intrashelf platform lobes}

The NW-sourced intrashelf platform lobe system prograded into the Hoop area in Barremian time, and developed into lobe NW1 followed by lobe NW2 (Fig. 11). The high-resolution data are crucial for determination of the relative depositional timing between NW1 and NW2 (Electronic Supplement 3).

There are different interpretations on relative age, position and orientation of the prograding, SE-directed, fluvial to open-marine depositional system between Dimitriou (2014), Marín et al. (2017), Grundvåg et al. (2017) and Midtkandal et al. (2019a). This study supports and adds information to the work done by Midtkandal et al. (2019a) which was initially based on the mapping by Dimitriou (2014). The conventional 3D data, and particularly the high-resolution seismic data, show that the prograding unit coming in from northwest terminated a few kilometres before reaching the Apollo and Atlantis well locations (Figs. 6, 7 \& 8). Marín et al. (2017) identified the same progradational front and called it sequence S3. Grundvåg et al. (2017) mapped out their S3 to extend beyond the Apollo well but terminating before the Atlantis well. They also showed a sequence $\mathrm{S} 1$ that terminates at the location of our lobe NW2 front west of the Apollo well.

The age of the NW-sourced intrashelf platform lobe front is Barremian, based on seismic-to-well ties in the Fingerdjupet Subbasin (Fig. 10; Serck et al., 2017) and further supported by biostratigraphic information in the Apollo well (Fig. 4). This is in contrast to Marín et al. (2017) and Grundvåg et al. (2017) who proposed an Aptian or Albian age for their sequence S3 in the Hoop area by correlating it with lower parts of the Kolmule Formation. On the other hand, an Aptian-Albian age is likely for their S3 on the central Bjarmeland Platform where it is part of the intrashelf platform depositional system that prograded from northeast towards southwest. Here, their sequence S3 corresponds to lobe NE3 of Midtkandal et al. (2019a). However, the
NW-sourced intrashelf platform lobe system is older. It arrived and terminated within the Hoop area in the Barremian prior to the Aptian-Albian faulting (Figs. 6, 7, $8,9 \& 12 \mathrm{~A}$ ). In the Barremian, the NE-sourced sediment lobe system had not yet reached the Hoop area (Fig. 12A; Midtkandal et al., 2019a).

The unreleased gamma-ray log made available to our study indicates a coarser lithology in 7324/3-1, but still rather fine-grained, within the Kolje Formation than the dominantly mudstones penetrated in the adjacent Apollo and Atlantis wells (Fig. 6). The steeper oblique clinoforms revealed by the high-resolution seismic data (Fig. 8), in particular close to the northwestern subcrop limit of lobe NW2, may be related to even coarser-grained material. In general, the steepest clinothems are expected to have the largest potential for coarser-grained strata (GlørstadClark et al., 2011; Patruno et al., 2015).

\section{Aptian-Albian faulting and basin evolution}

The main phase of Early Cretaceous faulting in the Fingerdjupet-Hoop areas clearly postdates the Barremian intrashelf platform lobe system that prograded into the area from the northwest. In the Fingerdjupet Subbasin the faulting is dated to Aptianearly Albian, and the resulting depocentre was filled by Aptian-Albian sediments onlapping the eastern basin flank towards the Hoop area on the NW Bjarmeland Platform (Fig. 10; Serck et al., 2017). In the Hoop area it is difficult to constrain the timing of onset of this fault activity. No Aptian strata have been reported from the Apollo well located outside the main graben structures in the Hoop area. The main growth sequences within the graben fill are of Albian age, but thickening within the $\mathrm{H} 3-\mathrm{H} 4$ interval observed in the high-resolution data (Fig. 11) indicates that the onset of faulting likely occurred in the Aptian as in the adjacent Fingerdjupet Subbasin (Serck et al., 2017).

The widespread Aptian-Albian faulting in the Fingerdjupet-Hoop areas, associated with approximately $10 \mathrm{~km}$ of extension across the profile in Figure 10, caused subsidence extending northwards in the Barents Sea. This rift-related subsidence was superimposed on a regional north-south back-tilting associated with subsidence of the northern uplifted source area. As a consequence of these processes, the NW-sourced shelf platform lobes were transgressed and marine conditions were established all the way up to Svalbard and adjacent areas to the east (Fig. 12B). 

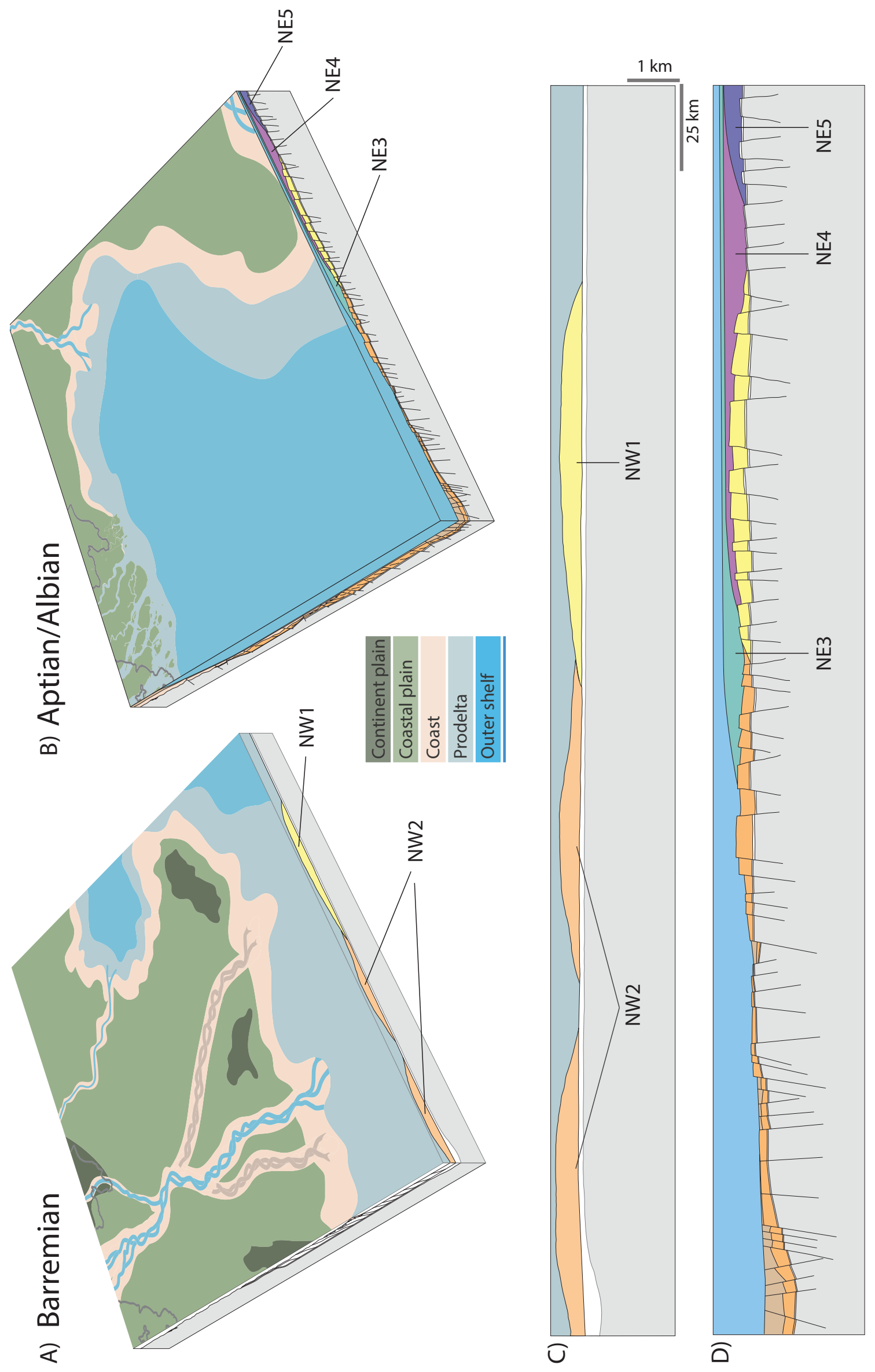

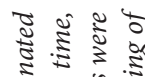

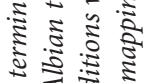

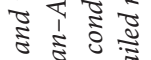
एक

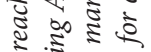

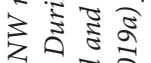

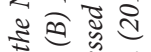
इ है उ उ. के टे है क्ष० इे है के की है ईँ

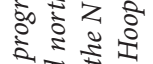
गิ

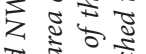
है ₹

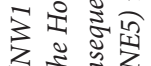

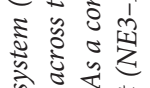
कै है के

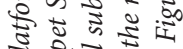
ग).

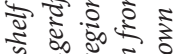

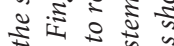
ई ई ट के के ปร

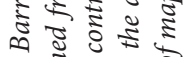
ई ङ इ 5 क त :

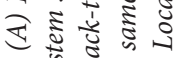
से के के क्ष ङ ह कू

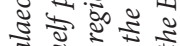
5. 5 क 5 : 5 ว.

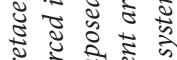
ड़ एँ है के के

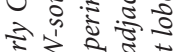
में क्ये है ₹ 5 के ई क्षे के है . ह ए

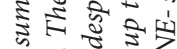

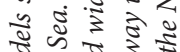

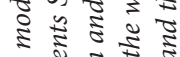
ली 걸 एक का कू

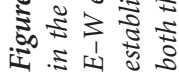




\section{Conclusions}

This study demonstrates the advantage of highresolution seismic data for seismic stratigraphic and fault interpretation. With up to four times better resolution, integration of the high-resolution data give more confidence in the interpretation of conventional seismic data. The main findings of this study can be summarised as follows:

- The main Early Cretaceous fault activity postdates the Barremian NW2 lobe. Detailed ties to the Apollo and Atlantis wells reveal an Aptian?-early Albian age of the main fault event. The onset of the major fault activity in the Early Cretaceous is difficult to date in the Hoop area because of a hiatus/condensed interval here, but correlations to the adjacent Fingerdjupet Subbasin support an Aptian age for the main faulting.

- The extension and associated faulting, combined with a regional north-south back-tilting, contributed to regional subsidence followed by flooding and transgression of the intrashelf platform lobes towards Svalbard where marine conditions dominated in Aptian-Albian time.

- Compared to previous studies, we provide a more detailed outline and better constraining of the timing of the SSE-prograding Barremian intrashelf platform lobe system, terminating a few kilometres before reaching the Apollo and Atlantis well locations in the Hoop area.

- Small-scale clinoforms are revealed within the largescale clinothems. Different clinoform geometries indicate variations in lithology within the study area but potential reservoir rocks have yet not been proved by exploration wells including the recent 7324/3-1 which is the first well penetrating the NW2 lobe.

- The high-resolution seismic tie-in to well logs also reveals a Hauterivian-Barremian age for the Lower Cretaceous Unconformity (LCU) where it is represented by the base of the Kolje Formation.

- The Jurassic-Cretaceous boundary (BC/H1) has been accurately defined by correlation of the highresolution seismic and well data.

- Stratification and local evidence of minor faulting within the condensed Knurr Formation, between BC/ $\mathrm{H} 1$ and $\mathrm{LCU} / \mathrm{H} 2$, is resolved in the high-resolution seismic data.
Acknowledgements. TGS, WGP Survey and VBPR are greatly acknowledged for providing seismic data. We acknowledge support from the Research Centre for Arctic Petroleum Exploration (ARCEx), funded by the Research Council of Norway (grant number 228107) together with ten academic and nine industry partners, and the Centre for Earth Evolution and Dynamics (CEED) funded by the Research Council of Norway through their Centre of Excellence grant 223272. Nina LebedevaIvanova is thanked for help and discussion on the seismic resolution problems. We thank Schlumberger for making Petrel software available at the University of Oslo. We also acknowledge the contributions by Alf Ryseth and Thorbjørn Dahlgren (Equinor) in providing important constraints on the interpretation. Constructive reviews from Peter Klitzke and one anonymous reviewer have improved the manuscript.

\section{References}

Antonsen, P., Elverhøi, A., Dypvik, H. \& Solheim, A. 1991: Shallow bedrock geology of the Olga Basin area, northwestern Barents Sea. American Association of Petroleum Geologists Bulletin 75, 11781194.

https://doi.org/10.1306/0C9B28FD-1710-11D7-8645000102C1865D.

Baltar, D. \& Barker, N. 2017: Reservoir quality prediction with CSEM. First Break 35, 48-53.

Baig, I., Faleide, J.I., Jahren, J. \& Mondol, N.H. 2016: Cenozoic exhumation on the southwestern Barents Shelf: Estimates and uncertainties constrained from compaction and thermal maturity analyses. Marine and Petroleum Geology 73, 105-130.

https://doi.org/10.1016/j.marpetgeo.2016.02.024.

Bugge, T., Elvebakk, G., Fanavoll, S., Mangerud, G., Smelror, M., Weiss, H.M., Gjelberg, J., Kristensen, S.E. \& Nilsen, K. 2002: Shallow stratigraphic drilling applied in hydrocarbon exploration of the Nordkapp Basin, Barents Sea. Marine and Petroleum Geology 19, 13-37. https://doi.org/10.1016/S0264-8172(01)00051-4.

Cattano, A., Correggiari, A., Langone, L. \& Trincardi, F. 2003: The late-Holocene Gargano subaqueous delta, Adriatic shelf: Sediment pathways and supply fluctuations. Marine Geology 193, 61-91. https://doi.org/10.1016/S0025-3227(02)00614-X.

Cohen, K.M., Finney, S.C., Gibbard, P.L. \& Fan, J.X. 2013: The ICS international chronostratigraphic chart. Episodes 36, 199-204.

Collanega, L., Massironi, M., Breda, A. \& Kjølhamar, B.E. 2017: Onset of N-Atlantic rifting in the Hoop Fault Complex (SWBarents Sea): An orthorhombic dominated faulting? Tectonophysics 706-707, 59-70. https://doi.org/10.1016/j.tecto.2017.04.003.

Corseri, R., Faleide, T.S., Faleide, J.I., Midtkandal, I., Serck, C.S., Trulsvik, M. \& Planke, S. 2018: A diverted submarine channel of Early Cretaceous age revealed by high-resolution seismic data, SW Barents Sea. Marine and Petroleum Geology 98, 462-476. https://doi.org/10.1016/j.marpetgeo.2018.08.037.

Dallmann, W.K. 1999: Lithostratigraphic Lexicon of Svalbard. Norwegian Polar Institute, Tromsø, $318 \mathrm{pp}$.

Dallmann, W.K. 2015: Geoscience Atlas of Svalbard. Norwegian Polar Institute Report Series 148, 292 pp.

Dimitriou, M. 2014: Lower Cretaceous Prograding Units in the eastern part of the SW Barents Sea. MSc thesis, University of Oslo, 98 pp.

Dypvik, H., Håkansson, E. \& Heinberg, C. 2002: Jurassic and Cretaceous palaeogeography and stratigraphic comparisons in the North Greenland-Svalbard region. Polar Research 21, 91-108. https://doi.org/10.3402/polar.v21i1.6476.

Faleide, J.I., Bjørlykke, K. \& Gabrielsen, R.H. 2015: Geology of the Norwegian Continental Shelf. In Bjørlykke, K. (ed.): Petroleum Geoscience: From Sedimentary Environments to Rock Physics, Springer, Berlin, Heidelberg, pp. 603-637.

https://doi.org/10.1007/978-3-642-34132-8_25. 
Gabrielsen, R.H., Færseth, R.B., Jensen, L.N., Kalheim, J.E. \& Riis, F. 1990: Structural elements of the Norwegian continental shelf Part I: The Barents Sea Region. Norwegian Petroleum Directorate Bulletin $6,1-33$.

Gjelberg, J. \& Steel, R.J. 1995: Helvetiafjellet Formation (BarremianAptian), Spitsbergen: characteristics of a transgressive succession. Norwegian Petroleum Society Special Publications 5, 571-593. https://doi.org/10.1016/S0928-8937(06)80087-1.

Glørstad-Clark, E., Faleide, J.I., Lundschien, B.A. \& Nystuen, J.P. 2010: Triassic seismic sequence stratigraphy and paleogeography of the western Barents Sea area. Marine and Petroleum Geology 27, 14481475. https://doi.org/10.1016/j.marpetgeo.2010.02.008.

Glørstad-Clark, E., Birkeland E.P., Nystuen, J.P. \& Faleide, J.I. 2011: Triassic platform-margin deltas in the western Barents Sea. Marine and Petroleum Geology 28, 1294-1314.

https://doi.org/10.1016/j.marpetgeo.2011.03.006.

Grundvåg, S.A. \& Olaussen, S. 2017: Sedimentology of the Lower Cretaceous at Kikutodden and Keilhaufjellet, southern Spitsbergen: implications for an onshore-offshore link. Polar Research 36, 1302124. https://doi.org/10.1080/17518369.2017.1302124.

Grundvåg, S.A., Marín, D., Kairanov, B., Śliwińska, K.K., Nøhr-Hansen, H., Jelby, M.E., Escalona, A. \& Olaussen, S. 2017: The Lower Cretaceous succession of the northwestern Barents Shelf: Onshore and offshore correlations. Marine and Petroleum Geology 86, 834857. https://doi.org/10.1016/j.marpetgeo.2017.06.036.

Grundvåg, S.A., Jelby, M.E., Śliwińska, K.K., Nøhr-Hansen, H., Aadland, T., Sandvik, S.E., Tennvassås, I., Engen, T. \& Olaussen, S. 2019: Sedimentology and palynology of the Lower Cretaceous succession of central Spitsbergen: integration of subsurface and outcrop data. Norwegian Journal of Geology 99, 1-33. https://doi.org/10.17850/njg006.

Henriksen, E., Bjørnseth, H.M., Hals, T.K., Heide, T., Kiryukhina, T., Klovjan, O.S., Larssen, G.B., Ryseth, A.E., Rønning, K., Sollid, K. \& Stoupakova, A. 2011: Uplift and erosion of the greater Barents Sea: impact on prospectivity and petroleum systems. Geological Society of London Memoirs 35, 271-281. https://doi.org/10.1144/M35.17.

Herron, D.A. 2011: Resolution. In Herron, D.A. \& Latimer, R.B (eds.), First steps in seismic interpretation. Society of Exploration Geophysicists no. 16, Tulsa, Oklahoma, pp 75-81. https://doi.org/10.1190/1.9781560802938.

Hurum, J.H., Roberts, A.J., Dyke, G.J., Grundvåg, S.A., Nakrem, H.A., Midtkandal, I., Sliwinska, K.K. \& Olaussen, S. 2016: Bird or maniraptoran dinosaur? A femur from the Albian strata of Spitsbergen. Artic Norway. Acta Palaeontologica Polonica 67, 137-147.

Jakobsson, M., Mayer, L., Coakley, B., Dowdeswell, J.A., Forbes, S., Fridman, B., Hodnesdal, H., Noormets, R., Pedersen, R., Rebesco, M., Schenke, H.W., Zarayskaya, Y., Accettella, D., Armstrong, A., Anderson, R.M., Bienhoff, P., Camerlenghi, A., Church, I., Edwards, M., Gardner, J.V., Hall, J.K., Hell, B., Hestvik, O., Kristoffersen, Y., Marcussen, C., Mohammad, R., Mosher, D., Nghiem, S.V., Pedrosa, M.T., Travaglini, P.G. \& Weatherall, P. 2012: The International Bathymetric Chart of the Arctic Ocean (IBCAO) Version 3.0. Geophysical Research Letters 39. https://doi.org/10.1029/2012GL052219.

Jelby, M., Grundvåg, S.A., Alsen, P., Śliwińska, K., Stemmerik, L., Helland-Hansen, W. \& Olaussen, S. 2018: Stratigraphic treasures of an "ugly duckling": towards an integrated basin model of the Lower Cretaceous Rurikfjellet Formation, Arctic Svalbard. 33rd Nordic Geological Winter Meeting, Abstract volume, p. 93-94

Johnson, H.D. \& Baldwin, C.T, 1996: Shallow clastic seas. In Reading, H.G. (ed.): Sedimentary Environments: Processes, Facies and Stratigraphy, 3d Edition, Blackwell Science, pp. 232-280.

Klausen, T.G., Ryseth, A.E., Helland-Hansen, W., Gawthorpe, R. \& Laursen, I. 2014: Spatial and temporal changes in geometries of fluvial channel bodies from the Triassic Snadd Formation of offshore Norway. Journal of Sedimentary Research 84, 567-585. https://doi.org/10.2110/jsr.2014.47
Klausen, T.G., Müller, R., Poyatos-Moré, M., Olaussen, S. \& Stueland, E. 2019: Tectonic, provenance and sedimentological controls on reservoir characteristics in the Upper Triassic to Middle Jurassic Realgrunnen Subgroup-Southwest Barents Sea. Geological Society of London Special Publications 495. https://doi.org/10.1144/SP495-2018-165.

Lebedeva-Ivanova, N., Polteau, S., Bellwald, B., Planke, S., Berndt, C. \& Stokke, H.H. 2018: Toward one-meter resolution in 3D seismic. The Leading Edge 37, 818-828. https://doi.org/10.1190/tle37110818.1.

Li, G., Li, P., Liu, Y., Qiao, L., Ma, Y., Xu, J. \& Yang, Z. 2014: Sedimentary system response to the global sea level change in the East China Seas since the last glacial maximum. Earth-Science Reviews 139, 390-405. https://doi.org/10.1016/j.earscirev.2014.09.007.

Liu, J.P., Milliman, J.D., Gao, S. \& Cheng, P. 2004: Holocene development of the Yellow River's subaqueous delta, North Yellow Sea. Marine Geology 209, 45-67. https://doi.org/10.1016/j.margeo.2004.06.009.

Maher, Jr, H.D. 2001: Manifestations of the Cretaceous High Arctic Large Igneous Province in Svalbard. The Journal of Geology 109, 91-104. https://doi.org/10.1086/317960.

Marín, D., Escalona, A., Śliwińska, K.K., Nøhr-Hansen, H. \& Mordasova, A. 2017: Sequence stratigraphy and lateral variability of Lower Cretaceous clinoforms in the SW Barents Sea. American Association of Petroleum Geologists Bulletin 101, 1487-1517. https://doi.org/10.1306/10241616010.

Maselli, V., Trincardi, F., Asioli, A., Ceregato, A., Rizzetto, F. \& Taviani, M. 2014: Delta growth and river valleys : the influence of climate and sea level changes on the South Adriatic shelf (Mediterranean Sea). Quaternary Science Reviews 99, 146-163.

https://doi.org/10.1016/j.quascirev.2014.06.014.

Midtkandal, I. \& Nystuen, J.P. 2009: Depositional architecture of a lowgradient ramp shelf in an epicontinental sea: the lower Cretaceous of Svalbard. Basin Research 21, 655-675. https://doi.org/10.1111/j.1365-2117.2009.00399.x.

Midtkandal, I., Nystuen, J.P. \& Nagy, J. 2007: Paralic sedimentation on an epicontinental ramp shelf during a full cycle of relative sea-level fluctuation; the Helvetiafjellet Formation in Nordenskiöld land, Spitsbergen. Norwegian Journal of Geology 87, 343-359.

Midtkandal, I., Faleide, J.I., Dahlberg, M.E., Dimitriou, M. \& Nystuen, J.P. 2014: The Lower Cretaceous strata in Svalbard and the Barents Sea; basin infill dynamics and palaeobathymetry. Geophysical Research Abstract EGU General Assembly Conference, pp. 2014-12638.

Midtkandal, I., Svensen, H.H., Planke, S., Corfu, F., Polteau, S., Torsvik, T.H., Faleide, J.I., Grundvåg, S.A., Selnes, H., Kürschner, W. \& Olaussen, S. 2016: The Aptian (Early Cretaceous) oceanic anoxic event (OAE1a) in Svalbard, Barents Sea, and the absolute age of the Barremian-Aptian boundary. Palaeogeography, Palaeoclimatology, Palaeoecology 463, 126-135. https://doi.org/10.1016/j.palaeo.2016.09.023.

Midtkandal, I., Faleide, J.I., Faleide, T.S., Serck, C.S., Planke, S., Corseri, R., Dimitriou, M. \& Nystuen, J.P. 2019a: Lower Cretacous Barents Sea strata: epicontinental basin configuration, timing, correlation, and depositional dynamics.. Geological Magazine. Doi: https://doi.org/10.1017/S0016756819000918

Midtkandal, I., Faleide, T.S., Faleide, J.I., Planke, S., Anell, I. \& Nystuen, J.P. 2019b: Nested intrashelf platform clinoforms - evidence of shelf platform growth exemplified by Lower Cretaceous strata in the Barents Sea. Basin Research. https://doi.org/10.1111/bre.12377.

Mondol, N.H. 2015: Well Logging: Principles, Applications and Uncertainties. In Bjørlykke, K. (ed.): Petroleum Geoscience: From Sedimentary Environments to Rock Physics, Springer, Berlin, Heidelberg, pp. 385-425.

https://doi.org/10.1007/978-3-642-34132-8_16.

Mountain, G. \& Proust, J.-N. 2010: The New Jersey Margin Scientific Drilling Project (IODP Expedition 313): Untangling the Record of Global and Local Sea-Level Changes. Scientific Drilling, 26-34. https://doi.org/10.5194/sd-10-26-2010. 
Mørk, A., Dallman, W.K., Dypvik, H., Johannesen, E.P., Larssen, G.B., Nagy, J., Nøttvedt, A., Olaussen, S., Pchelina, T.M \& Worsley, D. 1999: Mesozoic lithostratigraphy. In Dallmann, W.K. (ed.): Lithostratigraphic Lexicon of Svalbard, Review and recommendations for nomenclature use, Upper Palaeozoic to Quaternary bedrock, Norwegian Polar Institute, Tromsø, pp. 127-214.

Nemec, W. 1992: Depositional controls on plant growth and peat accumulation in a braidplain delta environment: Helvetiafiellet Formation (Barremian-Aptian), Svalbard. In McCabe, P.J. \& Parrish, J.T. (eds.): Controls on the distribution and quality of Cretaceous Coals, Boulder, Colorado, Geological Socitey of America Special Papers 267, pp. 209-226. https://doi.org/10.1130/SPE267-p209.

NPD. 2017: Factpages of Exploration Wellbores [Online]. Available at: http://factpages.npd.no/factpages/

Parker, J.R. 1967: The Jurassic and Cretaceous sequence in Spitsbergen. Geological Magazine 104, 487-505. https://doi.org/10.1017/S0016756800049220.

Patruno, S. \& Helland-Hansen, W. 2018: Clinoforms and clinoform systems: Review and dynamic classification scheme for shorelines, subaqueous deltas, shelf edges and continental margins. EarthScience Reviews 185, 202-233. https://doi.org/10.1016/j.earscirev.2018.05.016.

Patruno, S., Hampson, G.J. \& Jackson, C.A.L. 2015: Quantitative characterisation of deltaic and subaqueous clinoforms. EarthScience Reviews 142, 79-119. https://doi.org/10.1016/j.earscirev.2015.01.004.

Pellegrini, C., Maselli, V., Cattaneo, A., Piva, A., Ceregato, A. \& Trincardi, F. 2015: Anatomy of a compound delta from the postglacial transgressive record in the Adriatic Sea. Marine Geology 362, 43-59. https://doi.org/10.1016/j.margeo.2015.01.010.

Planke, S., \& Berndt, C. 2007: U.S. Patent No. 7, 221,620. Washington, DC: U.S. Patent and Trademark Office.

Planke, S., Mienert, J., Berndt, C. \& Åsheim, S. 2004: Ny metode for innsamling av høyoppløselig 3D seismikk. Geo 7, 24-25.

Planke, S., Eriksen, F.N., Berndt, C., Mienert, J. \& Masson, D.G. 2009: P-Cable high-resolution seismic. Oceanography 22, 85. https://doi.org/10.5670/oceanog.2009.09.

Polteau, S., Hendriks, B.W.H., Planke, S., Ganerød, M., Corfu, F., Faleide, J.I., Midtkandal, I., Svensen, H.S. \& Myklebust, R. 2016: The Early Cretaceous Barents Sea Sill Complex: Distribution, 40Ar/39Ar geochronology, and implications for carbon gas formation. Palaeogeography, Palaeoclimatology, Palaeoecology 441, 83-95. https://doi.org/10.1016/j.palaeo.2015.07.007.

Senger, K., Tveranger, J., Ogata, K., Braathen, A. \& Planke, S. 2014: Late Mesozoic magmatism in Svalbard: A review. Earth-Science Reviews 139, 123-144. https://doi.org/10.1016/j.earscirev.2014.09.002.

Serck, C.S., Faleide, J.I., Braathen, A., Kjølhamar, B. \& Escalona, A. 2017: Jurassic to Early Cretaceous basin configuration(s) in the Fingerdjupet Subbasin, SW Barents Sea. Marine and Petroleum Geology 86, 874-891.

https://doi.org/10.1016/j.marpetgeo.2017.06.044.

Sclater, J.G. \& Celerier, B. 1989: Errors in extension measurements from planar faults observed on seismic reflection lines. Basin Research 1, 217-221.https://doi.org/10.1111/j.1365-2117.1988.tb00017.x.

Smelror, M., Mørk, A., Monteil, E., Rutledge, D. \& Leereveld, H. 1998: The Klippfisk formation - a new lithostratigraphic unit of Lower Cretaceous platform carbonates on the Western Barents Shelf. Polar Research 17, 181-202. https://doi.org/10.3402/polar.v17i2.6618.

Smelror, M., Petrov, O., Larssen, G.B. \& Werner, S. 2009: Geological history of the Barents Sea. Geological Survey of Norway, $135 \mathrm{pp}$.

Smith, D.G., Harland, W.B., Hughes, N.F. \& Pickton, C.A.G. 1976: The geology of Kong Karls Land, Svalbard. Geological Magazine 113, 193-304. https://doi.org/10.1017/S001675680004320X.

Worsley, D. 2008: The post-Caledonian development of Svalbard and western Barents Sea Polar Research 27, 298-317.

https://doi.org/10.1111/j.1751-8369.2008.00085.x.
Worsley, D., Johansen, R. \& Kristensen, S.E. 1988: The Mesozoic and Cenozoic succession of Tromsøflaket. Norwegian Petroleum Directorate Bulletin 4, 42-65.

Yang, Z.S. \& Lieu, J.P. 2007: A unique Yellow River-derived distal subaqueous delta in the Yellow Sea. Marine Geology 240, 169-176. https://doi.org/10.1016/j.margeo.2007.02.008.

Yilmaz, Ö. 2001: Seismic data analysis: Processing, inversion, and interpretation of seismic data, 2nd edition. Society of Exploration Geophysicist, 2065 pp. https://doi.org/10.1190/1.9781560801580.

Århus, N. 1991: The transition from deposition of condensed carbonates to dark claystones in the Lower Cretaceous succession of the southwestern Barents Sea. Norwegian Journal of Geology 71, 259-263.

Århus, N., Kelly, S.R.A., Collins, J.S.H. \& Sandy, M.R. 1990: Systematic palaeontology and biostratigraphy of two Early Cretaceous condensed sections from the Barents Sea. Polar Research 8, 165194. https://doi.org/10.3402/polar.v8i2.6811. 